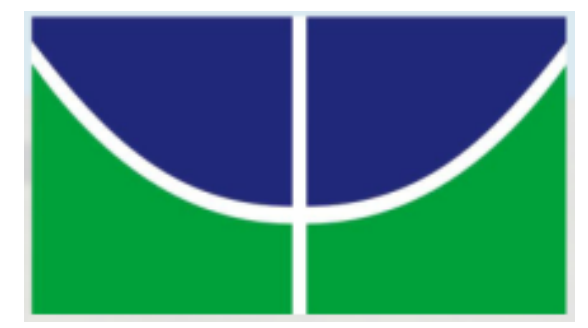

UNIVERSIDADE DE BRASÍLIA INSTITUTO DE RELAÇÕES INTERNACIONAIS

\author{
MONOGRAFIA DE GRADUAÇÃo
}

\title{
O Complexo Regional de Segurança do Sul da Ásia
}

\author{
Artur Andrade da Silva Machado
}

Professor Orientador: Alcides Costa Vaz

Brasília,

Março - 2010 


\author{
Universidade de Brasília \\ Instituto de Relações Internacionais
}

\title{
ARTUR ANDRADE DA SILVA MACHADO
}

\section{O Complexo Regional de Segurança do Sul da Ásia}

\author{
Monografia de Graduação em Relações \\ internacionais apresentada ao Instituto \\ de Relações Internacionais da \\ Universidade de Brasília, sob orientação \\ do Prof. Dr. Alcides Costa Vaz.
}

Este exemplar corresponde à versão final da monografia defendida e aprovada, em 16 de dezembro de 2009, pela Banca examinadora, cujos componentes são:

Prof. Dr. Alcides Costa Vaz

Instituto de Relações Internacionais - UnB

Profa. Dra. Maria Helena de Castro Santos

Instituto de Relações Internacionais - UnB

Prof. Dr. Lytton Leite Guimarães

Núcleo de Estudos para Ásia - UnB 


\section{FICHA CATALOGRÁFICA:}

Machado, Artur Andrade da Silva

O Complexo Regional de Segurança do Sul da Ásia /

Artur Andrade da Silva Machado. - - Brasília, DF: Instituto de

Relações Internacionais - Universidade de Brasília, 2009.

66 pp.; il

Orientador: Alcides Costa Vaz.

Monografia (graduação) - Universidade de Brasília, Instituto de Relações Internacionais.

1.Índia; 2.China; 3. Paquistão; 4.Sul da Ásia; 5.Segurança Internacional. I.Vaz, Alcides, II.Universidade de Brasília, Instituto de Relações Internacionais, III.O Complexo Regional do Sul da Ásia.

\section{REFERÊNCIA PARA CITAÇÕES:}

MACHADO, Artur A. S. O Complexo Regional de Segurança do Sul da

Ásia. Monografia de Graduação. Instituto de Relações Internacionais da Universidade de Brasília: 2009. pp 66 


\title{
RESUMO
}

Nesta pesquisa, o Sul da Ásia é reconhecido como unidade regional coerente desde a perspectiva de fluxos de segurança entre atores coletivos. Por meio de método histórico-construtivista, o autor caracteriza e delimita geograficamente as interações com maior grau de politização da agenda dos atores existentes no Sul da Ásia (Índia, China, Paquistão, entre outros). A pesquisa tem enfoque em questões da área de Relações Internacionais, mas conceitos e preocupações de geografia, sociologia e psicologia também são abordados.

\begin{abstract}
$\underline{\text { ABSTRACT }}$
In this research, South Asia is acknowledged as a coherent regional unit through the analysis of security flows connecting collective actors. By dint of historicconstructivist method, the author characterizes and demarcates geographically the most critical interactions among South Asia's collective actors (India, China, Pakistan, among others). The investigation focuses on International Relations' issues, but concepts and concerns from geography, sociology, and psychology are taken into account likewise.
\end{abstract}





\section{SUMÁRIO}

Introdução

I. Discussão Teórica e Metodológica

i. A Origem Cognitiva da Noção de Região................................................... 04

ii. Regiões Internacionais no Estudo de Segurança Internacional............... 05

iii. A Teoria dos Complexos Regionais de Segurança.................................. 07

iv. Cooperação ou Conflito: caracterizando o nível regional...................... 09

v. Objeto e método de pesquisa.................................................................... 11

\section{Construção Histórica do CRS}

i. Sul da Ásia: ponto de partida espacial..................................................... 15

ii. Espaço Indiano: história de variedade e autonomia............................... 16

iii. Império Mogul: amarras entre duas civilizações.................................... 18

iv. Raj Britânico: limites do Complexo Regional....................................... 20

v. 1947: o nascimento de um Complexo Regional..................................... 24

III. Características e Operação do CRS

i. Eixo de Rivalidade: Índia-Paquistão........................................................ 28

ii. China: o terceiro pilar do sistema......................................................... 33

iii. Periferia: Tibete, Nepal, Butão e Sri Lanka........................................... 37

iv. Afeganistão, Pachtunistão e Mianmar................................................... 40

v. Atuação de Potências Externas................................................................ 43

IV. Análise Final \& Conclusões

i. Limites do CRS................................................................................... 48

ii. A Agenda Regional de Segurança.......................................................... 51

iii. Cooperação e Conflito: cenários possíveis?........................................... 55

$\begin{array}{ll}\text { V. Bibliografia } & 61\end{array}$ 


\section{Introdução}

Os objetivos desta monografia são delimitar e caracterizar o complexo regional de segurança do Sul da Ásia. A necessidade central de delimitar o objeto de estudo deriva de uma característica intrínseca ao conceito de região: a flexibilidade. A caracterização do complexo visa fundamentar os padrões de interação que sustentam a unidade regional do objeto de pesquisa. A análise que se pretende desenvolver, portanto, mostrar-se-á de utilidade para tentativas futuras de fundamentar e entender a interação dos atores coletivos presentes na geografia do Sul da Ásia, bem como para traçar cenários possíveis para essas interações.

Por aperfeiçoar o entendimento sobre as interações de segurança entre os atores coletivos no Sul da Ásia, esta monografia contribui para a área temática de segurança internacional e para a disciplina de Relações Internacionais. A linguagem pretendida e os conceitos utilizados apresentam utilidade também para campos diversos, como ciências políticas, geografia e sociologia, mas impera deixar claro que a leitura que se busca fazer sobre as interações no Sul da Ásia será limitada aos fenômenos que interessam para a lógica de segurança. Fluxos econômicos, identidades e signos sociais, jogos políticos, todos esses fatores apenas serão abordados, seguindo a metodologia indicada, quando justificarem a adoção de medidas excepcionais por parte dos atores coletivos na região.

Para cumprir com os objetivos propostos, a monografia está dividida em quatro grandes partes temáticas, cada uma das quais subdividida em seções que foram formuladas para atender a objetivos específicos.

A primeira parte traz uma discussão teórico-metodológica sobre o objeto de estudo em questão e sobre dificuldades de trabalhar com o conceito de regiões para estudar fenômenos de segurança internacional. Desde já é preciso salientar que as discussões de cunho geral empreendidas na primeira parte da monografia - os aspectos cognitivos do regionalismo e o desenvolvimento de regiões internacionais na literatura de segurança internacional - não serão esgotadas, uma vez que sua função é somente ilustrar o contexto em que está inserida a metodologia específica da pesquisa. Os fundamentos conceituais e metodológicos desta pesquisa serão discutidos na quarta e quinta sessões da primeira parte, respectivamente, mas adianta-se que apesar de o estudo trazer referência ao conceito de complexo regional de segurança definido por Buzan e Waever, a abordagem metodológica usada apresenta significativos aspectos originais do estudo em questão. 
Os limites do espaço regional serão demarcados por alusão a processo histórico de construção dos padrões de identidade de atores e securitização de processos. A segunda parte da monografia cumprirá a função de identificar como as interações dos atores no Sul da Ásia evoluíram de modo a impor limites à própria geografia que lhes presta. Além disso, a passagem pelo processo de construção histórica permitirá identificar o surgimento e a institucionalização das mais básicas características do complexo regional visado, as quais reconhecem implicações para a futura caracterização do complexo em períodos contemporâneos.

A terceira parte, que leva o título da própria monografia, visa avaliar criticamente o quadro contemporâneo de manutenção e evolução das características encontradas na segunda parte. O complexo de segurança do Sul da Ásia terá seus componentes e atores identificados e analisados progressiva e separadamente, de modo que densa discussão sobre a coesão do todo se torne possível. A unidade do complexo, que será objeto de discussão somente na última parte da monografia, não reside na existência de agendas comuns, mas sim de perpetuação de tipos de interação, fundamentados na polaridade e polarização dos atores da região, e de suas consequências. Por isso, entender como cada um dos atores formula percepções, interesses e políticas é especialmente importante no caso do Sul da Ásia.

Apresentados todos os elementos necessários para concluir os objetivos da monografia até a terceira parte, a quarta parte se justifica para resumir, discutir e avaliar criticamente as questões propostas, apontando para os avanços que a monografia promove sobre a literatura existente. É nessa parte que será encerrada a discussão sobre os limites do Sul da Ásia e é também na qual será apresentada a agenda de segurança regional a que subscrevem os diversos atores coletivos do Sul da Ásia. Por último, uma discussão analítica contrastando cenários de cooperação e conflito para o escopo regional será desenvolvida por meio de alusão a hipóteses simplificadas da literatura das Relações Internacionais. A conclusão, assim como qualquer outra de sua espécie, nada mais é do que uma sugestão subjetiva para interpretação dessas variáveis de delimitação e caracterização que permeiam todo o texto da monografia. 


\section{Discussão Teórica e Metodológica}

\section{A Origem Cognitiva da Noção de Região}

O objetivo desta seção não é, como poderia significar o título, fundamentar e discutir o conceito de região por meio de teoria cognitiva. Assumir esse tipo de discussão teria o efeito indesejado de desvirtuar o foco, já extenso, da monografia ${ }^{1}$. O que se espera com esta seção é apontar riscos que derivam da origem cognitiva da noção de região para o estudo de regiões ontológicas. Desse modo, uma breve esquematização do funcionamento cognitivo a que se presta o conceito de região na mente humana será desenvolvida como um meio para argumentar que uma determinada sequência metodológica é necessária durante o processo de delimitação de regiões.

Desconsiderados os extremos de sofisticação conceitual e imprecisão que o emprego generalizado do termo região lega ao conceito, pode-se argumentar que este é fruto de impulsos cognitivos naturais face uma necessidade de classificação do espaço físico. Assim como a mente humana discrimina e nomeia diferentes frequências luminosas para traduzi-las em termos de cores, observadores de espaços geográficos sentem necessidade de fragmentar a realidade que contemplam de modo a melhor entendê-la. Embora o primeiro seja automático e o segundo desejado, ambos os processos são similares em seu funcionamento mental.

Durante um processo de segmentação cognitiva de uma realidade observada, há necessariamente três etapas claras: i) identificação de realidade maior; ii) definição de critério de segmentação; e iii) delineamento e definição de realidades menores.

Esse tipo de processo mental está por trás da característica mais básica do conceito de região, a verificação de conglomerados geográficos homogêneos internamente e heterogêneos face à realidade no seu exterior. As recorrentes tentativas de delimitar fronteiras entre regiões são, portanto, consequências da busca pelo entendimento de alterações na realidade observada desde uma perspectiva espacial.

É importante notar, ademais, que a terceira etapa do processo destacado delineamento e definição de realidades menores - é consequência quasi-objetiva das outras duas, o que fica claro ao observar as consequências de alterar a segunda etapa indicada. Se, ao

\footnotetext{
${ }^{1}$ A relação entre a o instrumento conceitual de região e processos de cognição mental está sendo desenvolvida em artigo próprio. MACHADO, Artur A. \& TORRES, Heitor F. S. Regional cutting edge for globalization. (Ainda não publicado).
} 
analisar um determinado espaço, o observador dá mais atenção para alterações em vegetação e relevo, naturalmente esse espaço será segmentado de modo que a realidade geológica e da vegetação de cada infra-espaço (região) derivado seja a mais diferente possível das realidades de seus pares, assegurado que cada um apresente o máximo possível de unidade interior.

A possibilidade de emprego do conceito de região nas ciências humanas, nas Relações Internacionais e no estudo da segurança internacional deve-se ao fato de que qualquer realidade espacial pode ser segmentada de diferentes maneiras, enfatizando diferentes características dessa realidade durante o processo de segmentação. Genericamente, o estudo de regiões internacionais ocorre via a delimitação de conglomerados geográficos singularizados e diferenciados de seus pares por interações específicas em níveis relevantes, como o supraestatal ou o transnacional. A mesma metodologia pode ser usada para delimitar regiões em termos do estudo de segurança internacional, garantido que cada região demarcada apresente interações singulares no campo de segurança, estratégia e defesa.

Impera notar, todavia, que uma região singularizada por sua homogeneidade em termos geológicos não será automaticamente útil para o estudo de interações no campo de segurança internacional. Por esse motivo, um estudo que demarca os limites de sua região de interesse antes de definir a realidade setorial com a qual o estudo está preocupado é impreciso.

Metodologicamente, o objeto espacial de estudos regionais deve ser definido em função de apuramento inicial dos fenômenos e processos diante dos quais se espera que determinada região faça sentido. Em outras palavras, os limites da região estudada devem ser demarcados por meio de interação dialética entre a proposta preliminar de região ontológica e a verificação posterior de sua homogeneidade espacial à luz dos fenômenos que se tem interesse em estudar.

Em termos práticos, o caráter cognitivo da noção de região exige em estudos regionais se observem diretrizes específicas para que o reconhecimento de regiões institucionalizadas no conhecimento científico ou a incorporação de marcos teóricos descontextualizados não invertam ou corrompam a lógica metodológica indicada. Assim, apesar de o Sul da Ásia já contar com importantes propostas de definição geográfica, a questão dos limites do Complexo Regional do Sul da Ásia é uma das maiores preocupações desta monografia.

\section{Regiões Internacionais no Estudo de Segurança Internacional}

Quatro fenômenos históricos na ontologia das relações internacionais foram responsáveis por ocasionar transformações no modo como a epistemologia de segurança 
internacional conceitua regiões internacionais: i) a II Guerra Mundial; ii) o processo de integração europeu; iii) a Guerra Fria; e iv) a Globalização.

A II Guerra Mundial e a consequente ampliação de escopo de entendimento do sistema internacional para além dos limites da política europeia teve papel importante na incorporação do conceito de região ao léxico epistemológico da disciplina de Relações Internacionais, durante a década de 1950. Importantes teóricos nesse processo, em que havia grande interação com a geopolítica, foram A. F. K. Organski ${ }^{2}$ e Karl Deutsch ${ }^{3}$.

Durante as décadas de 1960 e 1970, o processo de integração europeia trouxe ímpeto para a literatura nascente e repercutiu na disseminação de conceitos regionais sob as óticas econômica $^{4}$ e de segurança ${ }^{5}$, sendo que um viés normativo que relacionava ordem e integração regional foi institucionalizado no campo como imperativo ideológico e conceitual. Esses estudos pioneiros enfrentaram críticas metodológicas durante o período da onda behaviorista, que falseou empiricamente a validade dos fluxos observados ${ }^{6}$.

Ao longo das décadas de 1970 e 1980, sob influência da Guerra Fria e da globalização incipiente, a literatura de regiões na área de segurança internacional foi interrompida devido à fixação do campo com teorias do debate neo-neo, de nível sistêmico. Muitos conceitos elaborados para o nível sistêmico foram depois transportados ou adaptados para o nível regional, como são os casos das teorias da Estabilidade Hegemônica ${ }^{7}$, da Transição de Poder $^{8}$, do dilema de segurança waltziano e dos regimes de segurança de Jervis.

O mecanismo do dilema de segurança de Waltz descreveu como Estados são alçados para um sistema coletivo de armamentismo e punições fatais a partir de tentativas individuais de maximizar a própria segurança ${ }^{9}$. De outro lado, a teoria de regimes de Jervis afirma que a institucionalização de normativa eficiente para regular interações estatais no campo da segurança pressuporia algumas condições necessárias como: aval das grandes potências; entendimento compartilhado de ganhos coletivos com a cooperação; existência de valores

\footnotetext{
2 ORGANSKI, AFK. World Politics., 1958

${ }^{3}$ DEUTSCH, Karl et al. Political Community in the North Atlantic Area, 1957;

${ }^{4}$ Ver, por exemplo, BRECHER (1963) e ZARTNAN (1967).

${ }^{5}$ DEUTSCH, Karl. "Security Communities”, 1961

${ }^{6}$ KNORR, Klaus \& ROSENAU, James (Eds). Contending approaches to international politics. 1969. Ver também:

THOMPSON, William. The Regional Subsystem: A Conceptual Explication and a Propositional Inventory. 1973

${ }^{7}$ Ver, por exemplo, GILPIN, 1981; WALTZ, 1979; KRASNER, 1985; STRANGE, 1983; KEOHANE, 1984.

8 Ver ORGANSKI, 1958; MORGENTHAU, 2003; RAPKIN, 2003.

${ }^{9}$ WALTZ, Keneth. Theory of International Politics, 1979
} 
compartilhados, principalmente com relação à proibição e à caracterização de ataques; e possibilidade das ações individuais serem mais dispendiosas do que custos de cooperação ${ }^{10}$.

Com o fim da Guerra Fria e a intensificação da globalização, a literatura regionalista passou por vertiginosa expansão. Depois do trauma causado pelo genocídio de Ruanda, em 1994, a Organização das Nações Unidas (ONU) elaborou verdadeira agenda de cooperação com organizações regionais ${ }^{11}$ e diversos autores começaram a apontar contribuições inestimáveis que processos de regionalização prestariam à paz e à segurança internacionais ${ }^{12}$. Em 1995 com Fawcett e Hurrell e novamente em 2001 com Schuls et al $^{13}$, houve tentativas de explicar as novas ondas de regionalismo por meio de causas econômicas e de segurança. Destaque deve ser direcionado para o estudo de Lemke, que renovou o conceito de subsistema regional $^{14}$, e para a importante discussão sobre a relação entre globalização e regionalização ${ }^{15}$.

Também nesse período, desenvolveram-se as duas mais importantes ferramentas conceituais em voga na literatura atual. Em 1997, Lake e Morgan utilizaram empiricamente uma primeira versão do conceito de Complexo Regional de Segurança, desenvolvido por Buzan em $1983^{16}$, para analisar interações nas diversas regiões do globo, consequentemente submetendo a teoria a um primeiro teste empírico ${ }^{17}$. No ano seguinte, Adler e Barnett lançaram o influente livro Security Communities, que aperfeiçoou o conceito inicialmente formulado por Deutsch ${ }^{18}$, contudo, para os autores, comunidade de segurança seria uma comunidade na qual as diversas populações componentes mantêm expectativas dependentes de mudanças pacíficas. ${ }^{19}$

\section{A Teoria dos Complexos Regionais de Segurança}

A teoria dos Complexos Regionais de Segurança (CRS) desenvolvida em 2003 por Buzan e Waever é o marco teórico inicial, a partir do qual se desenvolve esta monografia. Sua vantagem sobre os demais conceitos antecedentes se manifesta em dois aspectos principais: i) a possibilidade de apreciar um variado leque de dinâmicas de forma holística (comparando

\footnotetext{
${ }^{10}$ JERVIS, Robert. Security Regimes. 1995.

11 WEISS, Thomas (Ed.). Beyond UN Subcontracting: Task-Sharing with Regional Security Arrangements and Serviceproviding NGOs, 1998.

${ }^{12}$ FAWCETT, Luise. Exploring Regional Domains: A Comparative History of Regionalism, 2004.

${ }^{13}$ FAWCETT, Luise \& HURREL, Andrew (Eds.). Regionalism in World Politics., 1995; e SCHULZ et al, Regionalization in a Globalizing World: A Comparative Perspective on Forms, Actors and Process., 2001.

${ }^{14}$ LEMKE, Douglas. Regions of $W$ ar and Peace, 2002.

${ }^{15}$ Ver, a esse respeito, CHA (2000) e GUEHENNO (1998).

${ }^{16}$ BUZAN, Barry. People, states, and fear: The national security problem in international relations, 1983.

${ }^{17}$ LAKE, David \& MORGAN, Patrick. The New Regionalism in Security Affairs, 1997.

${ }^{18}$ DEUTSCH, Karl. Security Communities, 1961
} 
diversas regiões e acrescentando fatos e processos nos níveis global e doméstico ${ }^{20}$ ); e ii) a incorporação da possibilidade de integração normativa e construção de comunidades de segurança, sem descartar a possibilidade de análises de regiões com alto grau de conflitividade ou com baixa expectativa de institucionalização.

Vinculada ao movimento de ampliação do conceito de segurança que teve lugar nas RI durante a década de 1990, a definição de um complexo de segurança que consta no último livro de Buzan e Waever sobre o tema é: "a set of units whose major processes of securitisation, desecuritisation, or both are so interlinked that their security problems cannot reasonably be analysed or resolved apart from each other". ${ }^{21}$ Fundamentando esse conceito, há o entendimento por parte dos autores de que segurança deve ser compreendida desde uma perspectiva pós-positivista, como fruto da internalização social de discursos securitizantes por determinada audiência.

Questões de segurança não seriam, portanto, título de uma classificação automática para determinado grupo de acontecimentos, mas sim: "[issues] posited (by a securitising actor) as a threat to the survival of some referent object (nation, state, the liberal international order, the rain forests), which is claimed to have a right to survive" ${ }^{22}$. Dessa forma, a resposta correspondente a uma questão de segurança seria também ação ou política extraordinária - "The special nature of security threats justifies the use of extraordinary measures to handle them,"23.

Com o alargamento do conceito de segurança, Buzan, Waever e Wilde estabeleceram uma nova forma de pensar em segurança, contextualizada por um movimento de discurso. Dado qualquer fato descrito como ameaça à segurança, os autores argumentam, é necessário perguntar a segurança de quế; e para quem². É por meio do rastreamento desses processos securitização e de sua classificação em conglomerados regionais que é possível demarcar os limites dos CRS. Nota-se que as fronteiras das "regiões internacionais" que são objetos de análise de Buzan e Waever não podem, por definição, gerar zonas de intersecção entre dois ou mais CRS e devem ser demarcadas segundo a verificação de duas possibilidades: "[either they are] zones of weak interaction, or they are occupied by an insulator (Turkey, Birmânia, Afghanistan)"25.

\footnotetext{
19 ADLER, Emmanuel \& BARNETT, Michael. Security Communities, 1998

${ }^{20}$ A preocupação em abordar as regiões internacionais em múltiplos níveis esteve presente na literatura desde suas formulações iniciais. Ver, por exemplo, o livro clássico de Russet (1967), que relaciona os níveis regional e sistêmico.

${ }^{21}$ BUZAN, Barry \& WAEVER, Ole. Regions and Powers: The Structure of International Security, 2003, p.44.

${ }^{22}$ Ibidem, p.71.

${ }^{23}$ BUZAN et al. Security: a new framework for analysis, 1998, p.21

24 Ibidem.

${ }^{25}$ BUZAN, Barry \& WAEVER, Ole. Regions and Powers: The Structure of International Security, 2003, p.41
} 
Observa-se, portanto, que Complexos Regionais de Segurança são demarcados segundo critério de interação deveras similar ao modelo genérico apresentado no início da primeira seção. O método de delimitar regiões desde a perspectiva de segurança internacional desenvolvido por Buzan e Waever prescinde a existência de processos de integração porque se baseia na verificação de níveis de "interdependência securitária", mais densos no interior de determinado complexo do que entre este e seu exterior. A utilização do nível regional é defendida de maneira bastante similar: "Since most threats travel more easily over short distances than over long ones, security interdependence is normally patterned into regionally based clusters: security complexes." 26

Para a configuração de CRS, portanto, os níveis de conflitividade e de confiança importam da mesma maneira, no sentido de que são responsáveis por elevar os índices de interdependência entre as unidades componentes.

Essas variáveis aparecem de maneira mais antagônica somente no momento de caracterizar um determinado CRS, o que exige pelo menos quatro critérios: i) a vinculação com a dimensão territorial, uma vez que o CRS deve estar ancorado em determinada região geográfica; ii) a distribuição de poder entre as unidades componentes, assumindo, para tanto, que o CRS está vinculado aos mesmos constrangimentos estruturais que impõe o sistema internacional anárquico; iii) os padrões e processos de securitização e dessecuritização, como conceituados no livro de $1998^{27}$; e iv) os padrões de amizade e inimizade entre as unidades, entendidos como variáveis independentes ${ }^{28}$.

\section{Cooperação ou Conflito: caracterizando o nível regional}

A partir do escopo epistemológico discutido até aqui, observa-se que há certa especialização das matrizes teóricas, cujas ontologias orbitam entre dois sistemas de interação centrais para as ciências sociais: a cooperação e o conflito. Segundo Giddens, o dilema entre consenso (cooperação) e conflito é um dos quatro vértices estruturantes do pensando sociológico $^{29}$, de modo que a epistemologia estaria fadada à polarização neste ponto.

Em interessante estudo, Väyrynen classificou as teorias de regiões internacionais em termos de extensiva dicotomia que opõe estudos sobre sistemas regionais a outros cujo intuito é

\footnotetext{
${ }^{26}$ Ibidem, p.4

${ }^{27}$ A referida teoria de securitização já foi resumida nesta mesma seção.

${ }^{28}$ BUZAN \& WAEVER. Opt cit.

${ }^{29}$ GIDDENS, Anthony. Sociologia, 2005
} 
analisar processos de construção de ordens regionais ${ }^{30}$. A partir dessa dicotomia, é possível desenvolver um continuum epistemológico, cujos extremos são dados por tipos puros baseados, de um lado em teorias de conflituosos subsistemas regionais, sob operação do dilema de segurança neo-realista; e, de outro lado, em teorias neoliberal-institucionalistas com enfoque na institucionalização de cooperação no nível regional.

O entendimento severamente específico que Adler e Barnett admitem para o conceito de comunidade coloca a teoria de Comunidades de Segurança em sintonia com os requisitos apontados na teoria de regimes de Jervis. Na sociologia tradicional, o termo comunidade, em oposição ao conceito de sociedade, seria entendido dentro de uma ótica de comportamento coletivo racional, como um composto de indivíduos compartilhando um mesmo objetivo ${ }^{31}$. Para Adler e Barnett, alternativamente, a existência de uma comunidade de segurança depende da existência de significados, valores, estruturas normativas, compromissos de longo prazo e identidades compartilhados coletivamente, além de múltiplos canais de comunicação e ausência de expectativa de guerra ${ }^{32}$.

Por outro lado, o conceito de Complexo Regional de Segurança constitui uma categoria genérica e abrangente que pode ser aplicada no estudo de regiões classificadas em ambos os extremos do espectro apontado por Väyrynen. Segundo a formulação de Buzan e Waever para o conceito, a caracterização de um CRS fundamenta-se em critérios de polaridade (estrutura de capacidades relativas) e polarização (padrões de amizade e inimizade). Caracterizados, os CRS devem ser enquadrados em categorias de classificação pré-estabelecida: i) regiões centralizadas, constituindo entorno regional de uma potência sistêmica ou institucionalizadas como Comunidades de Segurança; ou ii) regiões padrão (standard regions), com estrutura normalmente multipolar ${ }^{33}$, lógica de interação vestfaliana, e agenda de segurança marcada por questões políticas e militares $^{34}$.

Embora a classificação proposta por Buzan e Waever seja útil para caracterizar complexos regionais em termos de cooperação e conflito, ela não é suficiente. Isso porque ao restringir a análise a categorias estanques, a classificação torna-se dependente de hipóteses de cooperação e conflito pré-estabelecidas, abandonando outras possibilidades de explicação. Além disso, a classificação de Buzan e Waever perde certa capacidade de projetar cenários por

\footnotetext{
${ }^{30}$ VÄYRYNEN, Raimo. Regionalism: old and new, 2003.

31 TÖNNIES, Ferdinand, Community and Civil Society, 2001

32 ADLER, Emmanuel \& BARNETT, Michael. Security Communities, 1998

${ }^{33}$ Regiões caracterizadas pela presença de potências regionais também se enquadram nessa categoria.
} 
constituir um composto de hipóteses teóricas necessariamente vinculadas, de modo que a não satisfação de elementos isolados prejudica o poder de prescrição do todo. Para tornar a abordagem mais completa, durante a caracterização do CRS do Sul da Ásia nesta monografia, um leque mais variado de hipóteses de cooperação e conflito será discutido, com vistas a configurar o conjunto de forças independentes de um sistema.

\section{Objeto e Método de Pesquisa}

Aspecto central deste, e de qualquer outro estudo com abordagem em ou para o nível regional, é a necessidade de delimitar espacialmente a região ou as regiões que se pretende estudar. Deve-se discutir, portanto, os limites do objeto de análise de determinado estudo.

Observadas as exigências metodológicas levantadas na primeira seção, não será possível para este estudo apropriar-se de uma definição geográfica já formulada para o Sul da Ásia. Em termos institucionais, o Sul da Ásia não constitui organização regional própria e tampouco projeto de regionalismo, o que poderia indicar políticas de atores locais para definir seu próprio espaço regional. Além disso, a sub-região nomeada pela ONU como Sul da Ásia (Irã, Afeganistão, Paquistão, Nepal, Butão, Índia, Maldivas e Sri Lanka) ${ }^{35}$ é imprecisa para os propósitos deste estudo porque não foi formulada respeitando critérios de interação no campo de segurança, mas sim tendo em vista a organização de políticas da própria ONU.

Por outro lado, a definição espacial consolidada na bibliografia de referência para este estudo, que consta em capítulo específico da discutida obra de Buzan e Waever ${ }^{36}$, padece de vícios de critérios, que aqui se pretende evitar. O primeiro vício de critério ocorre porque os autores adotam um tipo de delimitação outside-in, na qual complexos regionais devem respeitar rigidamente as fronteiras de seus componentes estatais. Devido a esse critério, Buzan e Waever enfrentam de mãos atadas o dilema de considerar ou não o Afeganistão como parte do complexo regional, uma vez que são grupos populacionais, e não o Estado afegão, que interagem densamente com o Sul da Ásia. O segundo vício de critério se justifica porque o estudo de Buzan e Waever, por definição, visa segmentar todo o espaço planetário em complexos regionais auto-excludentes (sem áreas de intersecção). Desde a perspectiva "unirregional" adotada nesta monografia, esse critério gera a anomalia de desvencilhar o Sul da

\footnotetext{
${ }^{34}$ BUZAN, Barry \& WAEVER, Ole. Regions and Powers, 2003, pp. 55-62

${ }^{35}$ Divisão Estatística da ONU, disponível em

$<$ http://millenniumindicators.un.org/unsd/methods/m49/m49regin.htm>, ultimo acesso em 30/11/09

${ }^{36}$ BUZAN, Barry \& WAEVER, Ole. Ibdem, pp.
} 
Ásia de sua interação com a China, mesmo que esta seja mais importante para os padrões de securitização do complexo do que, por exemplo, o Sri Lanka.

Em vista do exposto, deve-se proceder com nova demarcação dos limites geográficos do CRS do Sul da Ásia específica para o estudo pretendido. O critério usado nesta monografia, que será desenvolvido ao longo de toda a parte II, busca submeter um espaço geográfico inicial (considerado um pressuposto ontológico) a uma relação dialética com a análise de interações históricas entre os atores coletivos do complexo no campo da segurança. Esse critério é ideal porque não faz distinção formal ou conceitual entre delimitação geográfica e caracterização de interações: ambas as medidas estão entrelaçadas historicamente.

Atesta-se que as fronteiras do complexo estudado são influenciadas, tão somente, pelos padrões de interdependência securitária entre atores relevantes. Dessa forma, essas fronteiras estão sujeitas a transformações intencionais - quando atores políticos mudam propositadamente a meta de alcance espacial de suas ações - ou ocasionais - quando a força de interações regionais incide estruturalmente sobre o comportamento dos atores.

Impera enfatizar que, embora esta monografia adote o conceito de complexo regional de segurança como peça central no delineamento da pesquisa, a metodologia preferida para manusear tal conceito é bastante diferente daquela sugerida por Buzan e Waever. É justamente essa distinção metodológica a maior contribuição desta monografia para o pensamento científico. Regiões, ou complexos regionais, deixam de ser entendidos como realidades geográficas estáticas, que devem ser apreendidas, para figurar como espaços de geografia dinâmica, cuja demarcação depende da compreensão sincrônica da interação dos atores regionais. A diferença metodológica permitirá traçar novo entendimento sobre o Sul da Ásia e culminará com resultados distintos dos que foram apontados pela bibliografia existente.

Presente também na segunda parte, mas principalmente nas partes III e IV, há ainda outro objetivo da monografia - caracterizar o complexo regional estudado em termos de cooperação e conflito. Nas Relações Internacionais, o debate sobre cooperação e conflito apresenta nuances particulares; sendo, portanto, diagnosticado em bibliografia especializada. A apresentação desta será drasticamente simplificada de modo a configurar ferramentas conceituais aqui denominadas de hipóteses de cooperação e conflito. Para tanto, o que se pretende é reduzir os argumentos centrais de cada matriz teórica em conjuntos binários de preceitos e cenários (conflituoso ou cooperativo); não sendo oportuno, portanto, discutir densamente a 
epistemologia, uma vez que cada teoria é de fato extremamente mais complexa do que as hipóteses apresentadas. Essas hipóteses estão resumidas no quadro 1, na página 14.

Como hipóteses de cenário conflituoso, considera-se: i) realismo clássico, cujo preceito enfatizado pela teoria descreve que atores (estatais) revisionistas ou imperialistas face à ordem estabelecida serão fonte de desestabilização que leva o sistema no qual estão inseridos ao $\operatorname{conflito}^{37}$; ii) neorrealismo defensivo, cujo preceito indica que, sob efeitos de estrutura anárquica, atores (estatais) visando maximizar suas próprias seguranças são impelidos ao sistema de auto-ajuda e à guerra ${ }^{38}$; iii) neorrealismo ofensivo, cujo preceito aponta para a configuração de sistema armamentista e com alta possibilidade de conflito devido ao interesse dos atores estatais em maximizar sua capacidade de exercer controle sobre os resultados da interação política ${ }^{39}$; iv) choque de civilizações, cujo preceito aponta para a incapacidade de cooperação entre civilizações ${ }^{40}$; e v) construtivismo, cujo preceito indica que há tendência de conflito quando atores estão inseridos em cultura que perpetua expectativas de conflito ${ }^{41}$.

Quanto às hipóteses de cooperação, serão adotadas: i) construtivismo, que sugere que diante de institucionalização de cultura de cooperação, o comportamento cooperativo tende a se perpetuar ${ }^{42}$; ii) idealismo clássico, segundo o qual a cooperação seria alcançada quando as populações incorporassem a percepção de que harmonia traz ganhos para o bem-estar social ${ }^{43}$; iii) tese da hegemonia cooperativa, segundo a qual ordens institucionais com confiança e previsibilidade sobre comportamentos pacíficos podem ser criadas a partir da vontade de potências hegemônicas em um sistema ${ }^{44}$; iv) síntese institucionalista, para a qual ordens institucionais com confiança e previsibilidade sobre comportamentos pacíficos podem derivar da construção de instituições funcionais por atores que visam ganhos absolutos ${ }^{45}$; e v) tese da paz democrática, em que há tendência de cooperação entre regimes democráticos ${ }^{46}$;

Finalmente, impera pontuar o que se entende por sistemas de cooperação e conflito e como estes podem ser verificados. Para os fins desta monografia, a distinção entre sistemas de

\footnotetext{
${ }^{37}$ Ver, por exemplo, Morgenthau (2003) e Gilpin (1981). Este, apesar de derivar muitos de seus conceitos na teoria de Waltz e escrever em época posterior, afirma ter maior vinculação com o realismo clássico.

38 Ver Waltz (1979)

${ }^{39}$ Ver Mearsheimer (2003)

${ }^{40}$ Ver Huntington (1993)

${ }^{41}$ Para este uso, ver Wendt (2007)

42 Para este uso, ver Wendt (2007)

43 Para discussão atualizada sobre harmonia social no meio internacional, ver Rawls (2002)

${ }^{44}$ Ver, por exemplo, Gilpin (1981) e Keohane (1984)

45 Ver, por exememplo, Keohane (1984) e Baldwin (1993)

46 Para uso genérico, ver Kant (1989)
} 
interação de cooperação e de conflito deve ser avaliada de acordo com três elementos da teoria de securitização: ator securitizante (quem securitiza); objeto securitizado (em nome de que se securitiza); e reação a ameaças ${ }^{47}$. Assim, haverá predominância de conflito em um dado CRS quando os principais atores securitizantes forem entidades coletivas infra-regionais (Estados, atores transnacionais, etc); quando os objetos securitizados mais frequentemente forem afeitos a interesses individuais dos atores regionais; e quando esses atores estiverem dispostos a adotar qualquer tipo de política (inclusive guerras e ataques nucleares) como reação a ameaças que os afligem. Por outro lado, configura-se a cooperação quando os padrões de securitização são mediados coletivamente no nível regional (mesmo na ausência de instituições próprias); quando os objetos securitizados forem afeitos aos interesses da região ou da paz regional; e quando os atores securitizantes aceitam limites morais ou racionais no delineamento de reações a ameaças.

Para cumprir com a caracterização dos cenários indicados e avaliar percepções políticas dos atores, a análise considerará primeiramente fontes primárias, como documentos negociados em instâncias regionais, declarações oficiais de políticas de defesa e de política externa, bem como discursos proferidos por representantes de atores coletivos. Como os canais oficiais não compreendem todos os atores coletivos e tampouco todas as políticas de atores Estatais, fontes secundárias, como artigos acadêmicos e análises de estudiosos locais, serão usadas para preencher lacunas restantes.

\begin{tabular}{|l|l|l|}
\hline \multicolumn{1}{|c|}{ Hipótese Teórica } & \multicolumn{1}{c|}{ Preceito/Medidor } & \multicolumn{1}{c|}{ Cenário Provável } \\
\hline Realismo Clássico & Estados revisionistas ou imperialistas & Conflito \\
\hline Neorrealismo defensivo & Anarquia + lógica de segurança & Conflito \\
\hline Neorrealismo ofensivo & Anarquia + desejo de ganhos políticos & Conflito \\
\hline Choque de Civilizações & Interação entre diferentes civilizações & Conflito \\
\hline Construtivismo H1 & Cultura de conflito & Conflito \\
\hline Construtivismo H2 & Cultura de cooperação & Cooperação \\
\hline Idealismo Clássico & Percepção de ganhos com harmonia & Cooperação \\
\hline Ordens institucionais & Construção de confiança & Cooperação \\
\hline Síntese Institucionalista & Preocupação com ganhos absolutos & Cooperação \\
\hline Paz democrática & Interação entre regimes democráticos & Cooperação \\
\hline
\end{tabular}

\footnotetext{
${ }^{47}$ BUZAN et al. Opt cit..
} 


\section{CONSTRUÇÃo HistóriCA DO CRS}

\section{Sul da Ásia: ponto de partida espacial}

De acordo com o método estabelecido, antes de definir o Sul da Ásia como complexo regional de segurança (CRS), ou mesmo como região, é necessário defini-lo como espaço geográfico. Esse espaço geográfico será tratado como pressuposto ontológico: um ponto de partida espacial de referência para a análise da formação do complexo de segurança do Sul da Ásia. Com sua interação com as sociedades, o espaço adquire nomes e funções, seus contornos são redesenhados, os tipos de interação e fluxos de toda ordem em seu interior ficam mais evidentes e o complexo de segurança pode ser visualizado com maior clareza.

A primeira noção morfológica que define virtualmente o Sul da Ásia é a península do subcontinente indiano. Ao sul, portanto, o espaço é abraçado pelas calmas águas do Oceano Índico, que é o elo marítimo entre o que ficou convencionado como Ocidente e Oriente, em termos planetários. Impulsionadas ocasionalmente pelas monções, as águas do Índico são propícias para navegação e têm efeitos diversos sobre a interação das populações locais ${ }^{48}$. Além de limite, portanto, o Índico é tanto caminho como encruzilhada, que lega à península participação inevitável em jogos estratégicos de largo alcance ${ }^{49}$.

As fronteiras ao norte são coincidentes com deformações geológicas. Embora unida continentalmente à Ásia e à Europa, a península é isolada destas pelo resultado de movimentações tectônicas, formando um subcontinente. Separado da Eurásia e da Arábia, o espaço é, portanto, circundado por obstáculos intransponíveis. O reconhecimento dessas fronteiras naturais se deve tanto por determinismo, evidente no caso do Himalaia (recorte histórico para a Pérsia clássica, para a expansão helênica de Alexandre e para a civilização chinesa $^{50}$ ), quanto por atribuição simbólico-social. A oeste, rumo à Arábia, o Himalaia e seus efeitos mantêm continuidade com uma rede de cordilheiras, destacando-se Pamir e a elevação chamada de Hindu Kush (matador de hindus) em clara evidência de sua função espacial.

Em grande parte dependente do degelo nas formações geológicas, há no subcontinente importantíssima rede fluvial. Começando em noroeste remoto, o Brahmaputra, eternizado como o limite da Bharat Varsa (Mãe Índia), desemboca no rio sagrado Ganges para formar, na

\footnotetext{
${ }^{48}$ HAAS, R. Naval Arms Limitation in the Indian Ocean, 1978

${ }^{49}$ RAIS, R. B. The Indian Ocean and the Superpowers. 1986

${ }^{50}$ BRAUDEL, F. The Perspective of the World., 1984
} 
atual região de Bengala, um emaranhado de rios que durante as monções se transforma em vasto lago, funcionando como limite natural à área de expansão de influência islâmica. No limite oeste, com importantes origens e afluentes fluviais na atual região da Caxemira chinesa e no Tibete, há o fértil vale do rio Indo, que permitiu florescer o contingente populacional que veio a primeiro povoar o subcontinente.

A solidez das fronteiras naturais do subcontinente indiano cumpriu função histórica de isolar as populações do espaço geográfico em questão do contato com grupos externos. Nem a civilização chinesa a nordeste e tampouco as expansões a noroeste do Império Mongol de Gengis Khan e da União Soviética foram capazes de adentrar o Sul da Ásia. Contudo, os fatores morfológicos que foram responsáveis por significativo isolamento do espaço indiano não tiveram o efeito de homogeneizar as populações em seu interior, caracterizado pela fragmentação sociopolítica.

\section{Espaço Indiano: história de variedade e autonomia}

As origens da civilização hindu, argumenta-se, remontam ao encontro entre migrantes arianos e antigos residentes do subcontinente indiano ${ }^{51}$, cujos antepassados haviam sido fundadores de um dos três mais antigos povoamentos da eurásia no vale do rio Indo. Após as Invasões Arianas, fundou-se a cultura védica, que ficou isolada de contato denso com populações exteriores ao subcontinente devido à unidade oferecida pelo espaço geográfico. Além da civilização hindu-védica, somente islâmicos persas e muçulmanos turco-mongóis teriam sucesso em imiscuir-se no espaço indiano. Todavia, fatores morfológicos e históricos no interior do espaço indiano tiveram efeitos de fragmentação sobre populações locais.

Separando a Índia Peninsular do norte continental, há as montanhas Vindhya, que, cobertas por mata densa, oferecem obstáculo para os fluxos sociais internos no subcontinente. A divisão entre norte e sul no espaço indiano marca limites entre zonas de influência das invasões arianas, observados em vários aspectos. Em termos de fenótipo populacional, separa homens claros e altos de morenos e baixos; em termos linguísticos, distingue entre idiomas arianos originados do sânscrito e línguas dravídicas; em termos religiosos, divide tradição hinduísta permeada pelo mundo pérsico de outra sob influência maior do xivaísmo.

Na península meridional, a tradição marítima, cuja importância comercial é patente desde o comércio entre Roma e as costas de Malabar e Coromandel, teve o efeito de conectar 
o subcontinente com Sudeste Asiático, África e Europa. Entre os séculos X e XII, os reis do Império Chola, de origem tâmil, conquistaram a atual ilha do Sri Lanka e dela penetraram o sudeste da Ásia até o Arquipélago de Malaio, permitindo o desenvolvimento de fluxos culturais importantes entre esses espaços, como o estabelecimento de círculo de influência budista ${ }^{52}$.

No norte continental, mais sujeito a migrações de populações islâmicas e à influência histórica de Pérsia e sucessores, há ainda outra divisão espacial entre centro habitado por cerco cultural hindu, com geografia de planícies; e entorno islâmico, cujo alcance geográfico chega, a oeste, até as populações ribeirinhas do Grande Deserto Indiano (Deserto do Thar) e, a leste, até a barreira fluvial da atual província de Bengala.

O caldo civilizacional hinduísta derivado da origem védica, que é responsável pelo mito de unidade do Ram Rajja (Reino de Rama) e pelo conceito de Cakravartim (imperador universal); é, portanto, matizado por indelével diversidade cultural e linguística ${ }^{53}$, que tem reflexos na organização política do espaço indiano. A autoridade política e a vinculação identitária internas no subcontinente têm caráter provincial e regional.

Durante a maior parte da história do espaço indiano, a autoridade política foi exercida de maneira quasi-territorial ${ }^{54}$, na qual as unidades políticas principais eram vilas ${ }^{55}$. Para cada vila (povoado minimamente urbano), havia uma instituição governamental genérica, a panchayat (conselho dos cinco), geralmente responsável pela arbitragem de conflitos e demais funções judiciais. A panchayat, que por vezes também regulava normas de casta e de comércio, convivia com diversas formas de "poder executivo", que podia ser exercido por oligarquia de principais autoridades das castas, por líder hereditário ou por agente de grande senhor de terras. Via de regra, as diversas vilas nutriam rede de relações com o campesinato periférico e estavam inseridas em cadeia de clientelismo com vilas ou reinos maiores.

Essa diversidade nos tipos e nas relações de autoridade política de certo modo inerente ao espaço indiano levou Adam Watson a descrever o "sistema indiano" tradicional como um amálgama anárquico de várias autoridades independentes e unidades diversas ${ }^{56}$. O objeto de estudo que motivou a análise de Watson foi a estrutura política existente no Sul da Ásia

\footnotetext{
${ }^{51}$ BRYANT, Edwin The Quest for the Origins of Vedic Culture: The Indo-Aryan Migration Debate., 2004

52 SENEVIRATNE, H.L. The Work of Kings: The New Buddhism in Sri Lanka, 1999

${ }^{53}$ Há no subcontinente indiano mais de 20 grupos linguísticos principais e inúmeros dialetos.

${ }^{54}$ Limites espaciais de autoridade não eram demarcados juridicamente, mas por alcance efetivo e transitório do jogo de poder local.

${ }^{55}$ Havia também outras formas de organização política como reinos, domínios e regiões.

56 WATSON, Adam. A Evolução da Sociedade Internacional. 2004
} 
durante a construção do Império Mauriano descritas pelo principal conselheiro político do império, Kautilya. Em sua principal obra, Arthashastra, Kautilya precede Maquiavel ao tentar reduzir a complexidade do sistema indiano a uma receita para expandir o alcance imperial da autoridade do "príncipe conquistador". Na descrição de Kautilya, padrões de amizade e inimizade eram deduzidos pela posição territorial de outras fontes de autoridades ${ }^{57}$.

Essa caracterização básica da autoridade no "sistema indiano antigo" compartilhada por Kautilya e Watson pode ser estendida a toda a história do espaço indiano até a passagem do século XVIII para o XIX, uma vez que somente durante os 100 anos de domínio britânico foi o espaço indiano mantido unido como unidade política. Por vezes impérios e domínios alcançaram relativo sucesso em submeter largas regiões a um único jugo administrativo, mas essas situações revelaram-se nunca perenes ou foram incapazes de suplantar a estrutura básica de autoridade fragmentada existente no espaço indiano.

De maneira atemporal, a unidade cultural indiana sugerida pelo escopo hinduísta deve ser relativizada e reinterpretada à luz da proliferação de células culturais diversas e da estrutura sociopolítica fragmentada. O tradicional esquema de quatro castas principais (desconsiderados os dalits, que não constituem casta) é uma simplificação teórica da realidade hindu, uma vez que para cada casta correspondem milhares de subcastas, em cada nível mais especializadas em nichos profissionais ${ }^{58}$. A essa estrutura inicial, deve-se adicionar ainda centenas de tribos espalhadas pelos rincões do subcontinente, bem como a permeabilidade histórica do espaço indiano a acolhimento e miscigenação cultural de minorias como a islâmica e a sikh.

\section{Império Mogul: amarras entre duas civilizações}

O império Mogul grassou por cerca de 250 a 350 anos e atou as civilizações hinduísta e islâmico-muçulmana no subcontinente indiano. Como foi elaborado, a interação entre hinduísmo e islã é uma constante histórica na formação das sociedades indianas, sendo que a própria instalação do Império Mogul ocorreu sobre o esboroamento de um sistema de sultanatos islâmicos, fundados por migrações de origem turca e afegã entre os séculos XI e XIV. A derrota do sultanato de Delhi por Barbar, de tribos turco-mongóis vindas de estepes da Ásia central é o marco para o surgimento do Império Mogul, em 1526.

\footnotetext{
${ }^{57}$ SHAMASASTRY, R. Kautilya's Arthashastra, 1923. disponível em: Internet Indian History Sourcebook.

${ }^{58}$ CARDOSO, K. et al. The Indian Caste System and the Issue of Untouchability. 2009
} 
O longo período de interação forçada entre islâmicos e hindus foi marcado por férteis manifestações artístico-culturais e inovações na arquitetura ${ }^{59}$. As populações hinduístas, principalmente as situadas nas planícies setentrionais, demonstraram aptidão natural para absorção de costumes, manifesta nas transformações de vestuário, de linguagem (com a criação do Urdo e do Hindustani) e de direito ${ }^{60}$ e na adoção de práticas tipicamente islâmicas, como a purdah (exclusão de mulheres). Todavia, a despeito de amarras culturais indestrutíveis estabelecidas por meio século de domínio islâmico sobre o espaço indiano, não foi possível que dessa interação emergisse matriz social ou cultural unitária no Sul da Ásia; perpetuando-se, dessa feita, diferenças civilizacionais. Dois fatores são importantes para entender a perpetuação dessas diferenças: um administrativo e outro cultural.

Em termos administrativos, a preservação da unidade hindu deriva da incapacidade, em termos demográficos, por parte dos imigrantes islâmicos de povoar ou mesmo de monopolizar a administração do subcontinente indiano. Burocratas e líderes militares hindus, das castas brâmane e kshatriya foram admitidos em altos postos da administração mogul. As vilas e comunidades regionais mantiveram a mesma organização política local, na maior parte das vezes adicionando-se somente dois novos postos: um governador mogul (subahdar ou nazim) e um ministro de finanças que, não necessariamente mogul, era o responsável pela arrecadação de tributos sobre a terra ${ }^{61}$. Nas atividades produtivas, da mesma forma, as únicas províncias nas quais a população muçulmana superava a hindu eram Punjabe e Bengala. Os hindus sempre constituíram maioria em atividades como trato da terra, metalurgia e religião.

Em termos culturais, a preservação de maioria populacional com forte vinculação identitária com o hinduísmo se justifica devido a efeitos de adaptação cognitiva do sistema de castas à nova realidade. Naturalmente os imigrantes seriam classificados de acordo com o princípio de pureza, basilar no sistema de $\operatorname{castas}^{62}$, e agrupados em categoria própria. Com o tempo, os muçulmanos mogul passaram a ser associados com corrupção, anarquia e ilegalidade ${ }^{63}$ e criou-se o termo m'leccha, aplicado a todos os não-hindus.

Durante o período do Império Mogul, portugueses, holandeses, ingleses e franceses estabeleceram feitorias e estabelecimentos comerciais privados ao longo da costa indiana. Motivados pela hostilidade aos muçulmanos que já havia na península ibérica à época, os

${ }^{59}$ HARLE, J.C. The art and architecture of the Indian Subcontinent, 1994

${ }^{60}$ SEN, Amartya. The Argumentative Indian. Writings on Indian Culture, History and Identity. 2005

${ }^{61}$ TINKER, Hugh. India and Pakistan: a political analyzis. 1967

${ }^{62}$ CARDOSO, K et all. Opt cit. 
pioneiros portugueses optaram por desfavorecer a administração mogul e incentivar populações locais hinduístas, enquanto ingleses não faziam distinção entre classes de indianos.

A transição formal entre o Império Mogul e o Domínio Britânico, todavia, é difícil de pontuar, sendo que a fragmentação de autoridade é importante também nesse processo. $\mathrm{O}$ século XVIII foi para o espaço indiano um período de intensa instabilidade política, no qual invasores persas e tribos afegãs Pachtun saquearam Delhi e autoridades locais e regionais passaram a exercer o controle de facto sobre vastas áreas do Império ${ }^{64}$. No zênite do declínio, o Império Mogul foi acossado pelo surgimento de forte domínio regional Sikh e de projeto hindu de Império Federativo Maratha, que assumiria o controle de grande parte do território do subcontinente pouco tempo antes de se enfraquecer pela sua própria fragmentação. Em meio a essas clivagens locais, a Companhia das Índias Orientais britânica consolidou-se como principal agente colonizador do subcontinente.

\section{Raj Britânico: limites do Complexo Regional}

"India is like a fortress, with the vast moat of the sea on two of her faces, and with the mountains for her walls on the remainder; but beyond these walls which are sometimes of by no means insuperable beight and admit of being easily penetrated extends a glacis of varying breadth and dimension. We do not want to occupy it, but we also cannot afford to see it occupied by our foes. We are quite content to let it remain in the hands of our allies and friends, but if rivals and unfriendly influences creep up to it, and lodge themselves right under our walls, we are compelled to intervene"

Lord Curzon, Vice-rei da Índia britânica $(1899-1905)^{65}$

A principal função a ser atribuída ao período de império britânico sobre o espaço indiano, para os fins desta monografia, é a de consolidação de limites consistentes para tipos e fluxos de interação política sustentando o subcontinente como região.

Muito embora a Companhia das Índias Orientais já estivesse instalada no subcontinente desde os primórdios do século XVII, somente no findar do século seguinte tornou-se sucessora do Império Mogul, posição apenas consolidada no início do século XIX mediante vitórias armadas sobre resistência Maratha. Em 1773 e 1784, o Parlamento Britânico

\footnotetext{
${ }^{63}$ TINKER, Hugh. Opt cit.

${ }^{64}$ RICHARDS, John F. The Mughal Empire., 1996

65 VENKATACHAR, C.S. Sea Power in the Indian Ocean, 1953, p.149
} 
publicou atos ordenando ingerência governamental na Companhia, que tivera dificuldades para saldar custos do monopólio comercial devido à concorrência holandesa no comércio de chá.

De início, o domínio britânico sobre as Índias fundou-se em princípios minimalistas. Somente com a ocorrência da Revolta dos Cipaios, em 1857, que o último imperador mogul foi destituído, sendo que até então lhe havia sido permitindo manter a corte em Delhi. O persa continuou a ser a língua nas cortes de justiça e na administração pública até a década de 1830 e o posto de Kasi - juiz muçulmano interpretador das leis locais - não foi abolido até 1864. Mesmo depois de instituído genuinamente o raj britânico, foi mantida a mesma divisão administrativa regional do Império Mogul, sendo que a muitas províncias foi garantida certa autonomia dentro de regime de suserania. Mais de 500 Estados Principescos foram geridos por administradores locais tão diversos como nizans e marajás, com destaque para domínio sikh em Punjabe e para Misore, Caxemira e Hyderabad.

A partir da segunda metade do século XIX, o governo britânico assumiu administrativamente as posses coloniais nas Índias, nomeando sequência de Vice-reis encarregados dos assuntos locais. Era a primeira vez que o subcontinente passava por experiência real de governo. Importantes investimentos em infraestrutura passaram a ser realizados, como a criação de exército local, de sistema de irrigação, de necessário Ministério da Agricultura e de novas universidades em Bombaim (atual Mumbai), Madras, Calcutá e Lahore. Pouco tempo depois, uma iniciativa universitária convocou congresso de extensão nacional, que futuramente se tornaria partido político central no processo de independência.

Em virtude do jogo geoestratégico externo à circunscrição europeia durante todo o século XIX, do qual foram protagonistas os impérios Britânico e Russo, desenvolveram-se em Londres preocupações com a defesa das posses coloniais nas Índias. O chamado Grande Jogo do século XIX teve descontínua participação francesa durante a expansão napoleônica e na virada para o século XX, mas as únicas grandes potências que tinham preocupações estratégicas para além de sua própria esfera regional eram Grã-Bretanha e Rússia Czarista ${ }^{66}$.

Grande parte das operações de inteligência militar do Grande Jogo parece ter tido seu peso histórico exagerado ${ }^{67}$. O maior objetivo do Império Russo era estender-se até conquistar saída leste para o Pacífico, de modo que na Ásia Central limitou-se o seu engrandecimento quando incorporou significativa parcela de terras povoadas por populações Tajiques, sem

${ }^{66}$ SARAIVA, J.F.S. História das Relações Internacionais Contemporâneas da sociedade internacional do século XIX à era da globalização, 2007 
adentrar o Afeganistão. Na Ásia Central, o maior interesse russo, a hegemonia sobre o mar Cáspio, concretizou-se já em 1813 após campanha militar contra a Pérsia, antes mesmo que o governo britânico decidisse por maior engajamento nas Índias.

Todavia, o Grande Jogo teve gigantescos efeitos sobre o espaço indiano, sobretudo em virtude de securitização de hipótese de expansão russa sobre as Índias britânicas, o que impulsionou série de medidas que teve o efeito de consolidar o subcontinente como espaço geográfico. A França napoleônica teve papel central no delineamento dessa ameaça, uma vez que, em 1798, Napoleão enviou uma frota francesa com pretensões territoriais sobre área entre o Egito e a Índia, que foi derrotada quando ainda estava próxima de Alexandria. Três anos depois, o Czar Paulo II, influenciado por antigas políticas da rainha czarista Catarina, propôs a Napoleão invasão conjunta sobre o espaço indiano ${ }^{68}$.

Em resposta, o então Governador-Geral da Índia, Lorde Wellesley, iniciou movimentos para expandir o território colonial sobre as áreas periféricas e consolidar a influência sobre os Estados Principescos clientes, de modo que já em 1842 uma comissão sinobritânica demarcava as fronteiras na região da Caxemira. Pesquisadores e aventureiros empreenderam grandes jornadas na tentativa de encontrar novas rotas para a Índia, desde pontos em Pérsia, Rússia e China ${ }^{69}$ e o conhecimento britânico da geografia do Sul da Ásia evoluiu tanto que foi possível a criação do corredor Wakhan, rota estratégica nas atuais relações entre China e Afeganistão.

Em 1812, no entanto, a suspeita de invasão conjunta perdeu força quando Napoleão invadiu a Rússia e a dinâmica do Grande Jogo mudou de foco para a Ásia Central, na qual a disputa por influência sobre Pérsia e Afeganistão era o nódulo de contenda entre as duas grandes potências. Por três vezes a Índia serviu de plataforma de organização de exército britânico para incurso militar no Afeganistão. Este tinha motivos próprios para expandir-se rumo à Índia, uma vez que ali havia parcela significativa do espaço natural das tribos Pachtun afegãs. Em 1893, todavia, a Grã-Bretanha conseguiu firmar tratado de limites com o Amir afegão, reconhecendo a Linha Durand (traçada sobre as montanhas de Barren).

Com a passagem da administração colonial para a esfera de poder do governo britânico, as políticas do Império sobre a periferia foram intensificadas, prezando-se sempre pela criação de Estados clientes circundando os limites do espaço indiano, o que fica patente

${ }^{67}$ MORGAN, Gerald. Myth and Reality in the Great Game, 1973

${ }^{68}$ EWANS, Martin. The Great Game: On the Practicability of an Invasion of British India, 2004 
na guerra empreendida contra o Butão e com a instituição de Estados clientes em Birmânia, Somalilândia, Singapura e no Golfo Pérsico. O Reino de Nepal, que havia iniciado conflito contra o domínio sikh, teve reconhecida sua soberania, por meio de Tratado de Amizade com a Grã-Bretanha em 1923. Esta estendia sua influência sobre o Nepal, dispensando o regime de suserania em virtude do apoio de Nepal à Coroa britânica durante a Revolta dos Cipaios.

Em 1907, a Grã-Bretanha e a Rússia assinaram acordos para formação de entente, que, similares à entente-cordiale entre britânicos e franceses, interromperiam momentaneamente a disputa por zonas de influência colonial na Ásia Central. A iminência da I Guerra Mundial levou os britânicos a últimos arroubos imperialistas sobre os Estados periféricos, lançando expedição militar sobre o Tibete entre 1903-04 (com quem fixou fronteiras dez anos depois) e pressionando o Butão pelo direito de incumbir-se de seus assuntos exteriores em 1910.

As Índias britânicas tiveram participação efetiva em ambas as Guerras Mundiais. Durante o entre-Guerras, a política colonial britânica já apresentava forte tendência de converter-se inteiramente para o Commonwealth, com aberta discussão sobre a independência da Índia. Na I Guerra Mundial, o engajamento das tropas coloniais ocorreu em grande parte dentro do continente europeu, mas entre 1915 e 1945 foi significativo o número de campanhas internacionais do exército indiano. Até 1919, as Índias britânicas enfrentaram alemães e turcos pelo controle de Sinai, chegando inclusive a conquistar Bagdá (1916) e a Palestina, com a Batalha de Megiddo (1918).

Durante a II Guerra Mundial, o exército das Índias britânicas, à época o maior contingente militar voluntário da história mundial (2,5 milhões de recrutas), atuou em batalhas no Oriente Médio, no Norte da África, na Indochina e na China. A maior ameaça, todavia, viria da tentativa japonesa de unificar dois espaços, o leste e o sul asiáticos, sob sua órbita de influência. Até 1942, o Japão imperial havia expandido enormemente seu alcance, com a conquista de Birmânia (atual Mianmar) e com campanhas ofensivas sobre o território indiano. Somente ao final da guerra, entre 1944 e 1945, os aliados foram capazes de reverter o quadro, de modo que as dinâmicas de independência na região, intensificadas com o final da Guerra, tiveram forte influência de mediação britânica.

${ }^{69}$ Ibidem. 


\section{7: o nascimento de um Complexo Regional}

"When People in India today want to talk about the recent past, they say, Since Independence...' Referring to the same period, Pakistanis invariably say, 'Since Partition....' In vast areas of the Indian Union, the people were quite unaffected by the division of the subcontinent; but scarcely a district, or even a family, of Pakistan was left untouched or unmarked by this upheaval",70

A partir de 1947, com a independência fracionada de Índia e Paquistão, sucedeu uma acirrada disputa pelos espaços provinciais nas fronteiras entre os sistemas populacionais hindu e islâmico, com grandes consequências para as atuais interações no Sul da Ásia. Desde que o possibilismo nacionalista atingiu o Sul da Ásia até o ano de 1947, todavia, o fracionamento do espaço indiano em territórios demarcados em bases civilizacionais não era compatível com os interesses de nenhuma das partes. Antes da decisão de ajustar diferenças culturais aos termos territoriais do estadocentrismo, o método mais lógico para indianos e ingleses seria a constituição de regime federativo e parlamentarismo bicameral. A história das independências das colônias britânicas no subcontinente indiano está, portanto, estruturada em torno do entendimento de como o nacionalismo modificou o espaço de diferenças culturais da política interna para a política internacional e para a lógica de Estado.

Até a independência, 90\% dos habitantes do subcontinente eram analfabetos e somente um em cada seiscentos era capaz de comunicar-se em inglês, de modo que a mediação política que resultou no arranjo de 1947 foi projeto de elites intelectuais ${ }^{71}$. Concomitantemente ao processo de "estatização da colonização britânica" da segunda metade do século XIX, surgiu uma classe média ascendente formada por profissionais de Estado, filósofos e letrados.

A população hindu saiu na dianteira nesse processo, uma vez que iniciativas para reinterpretar o hinduísmo em bases racionais remontam ao final do século XVIII. Embora essa nova classe majoritariamente hindu estivesse fixada em diversos postos da nova administração colonial, os britânicos enxergavam nos muçulmanos os principais aportes de liderança política local e regional. A política britânica, que muitos consideraram ter sido pautada pela máxima maquiavélica "dividir para governar", era na verdade opção conservadora por manter os líderes naturais do espaço indiano, derivados da estrutura do Império Mogul.

O "esclarecimento islâmico", que permitiu a ascendência de Muhammed Ali Jinnah no cenário político indiano foi fruto dos investimentos realizados na segunda metade do século

70 TINKER, Hugh. Opt cit. p. 69 
XIX e teve por objetivo adequar os princípios da religião à racionalidade europeia. O Paquistão unido e secular em sua administração, oposto ao regime islâmico afegão, foi fruto do ideal político de Jinnah, mas não pode ser mantido porque seu principal idealizador faleceu um ano após a independência ${ }^{72}$. Sob a liderança de Jinnah, houve inclusive uma articulação entre hindus e muçulmanos sobre a causa da autodeterminação indiana sendo que após o Massacre de Amritsar, mesmo Gandhi apoiou o movimento pan-islâmico do Tratado de Sèvres.

A fragmentação nacionalista, entretanto, não chegou à Índia antes da primeira Guerra Mundial. À época do último quarto do século XIX, hindus e muçulmanos organizavam-se em grupos políticos e pleiteavam junto à Coroa britânica alargamento do espaço para representação política na esfera nacional. $O$ primeiro desenho dos contornos do que seria o Estado islâmico no norte do espaço indiano nasceu em Cambridge na década de $1930^{73}$. Antes disso, o objetivo dos representantes dos indianos islâmicos organizados na Liga Muçulmana era a formação de federação com representação comunal. De fato, como ficara estabelecido pelo Pacto Lucknow, fixado em 1916 entre a Liga Muçulmana e o Partido do Congresso, um terço das cadeiras da câmara baixa do futuro congresso indiano seria reservado a muçulmanos.

A despeito dos esforços de aproximação, os lados foram polarizando-se gradualmente em arquétipos extremistas. Conforme a possibilidade de autodeterminação foi se tornando mais concreta, hindus abandonaram o compromisso com o Pacto de 1916 e tentaram estabelecer leis polêmicas, como a proibição do consumo de carne bovina no território indiano. A possibilidade de autodeterminação transfigurou-se em dois movimentos nacionalistas, que, alinhados com bases culturais e processos de securitização sociocultural, manipularam as percepções das massas na região.

De um lado, hindus ressaltavam contos épicos sobre Privthi Raj, o último rei hindu sobre Delhi, e sobre o príncipe Maratha, Sivaji, que lutou contra os esforços de Alamgir para estender o império Mogul. De sua parte, os muçulmanos contavam lendas sobre heróis mártires como Sayyied Ahmad Shahid, que protelou a constituição de reino Sikh em Punjabe. Além disso, diversas memórias de resistência contra vizinhos poderosos surgiram a partir de folclores regionais, como foi o caso de discursos de líderes de Assam sobre antigo rei, Chakradhvy Singha, que lutara pela independência contra Bengala. ${ }^{74}$

\footnotetext{
${ }^{71}$ HOBSBAWN, Eric. Era dos Extremos. O breve século XX: 1919-1991, 2009.

72 JALAL, Ayesha. The Sole Spokesman: Jinnah, the Muslim League and the Demand for Pakistan, 1993

73 TINKER, Hugh. Opt cit.

${ }^{74}$ CHANDAVARKAR, Rajnarayan. Imperial Power and Popular Politics, 1988
} 
De 1935 até pouco depois das independências, houve engajamento britânico em tentativas de mediar as elites políticas polarizadas, sendo que os indianos já entraram na segunda Guerra Mundial com a promessa de que receberiam a independência tão logo findado o conflito. Após ondas de violência social, o Vice-Rei britânico em ofício desde fevereiro de 1947, Lorde Mountbatten, surgiu com proposta de partição. Já na proposta de Mountbatten havia fórmula para ordenar a disputa por espaços, que consistia em duas diretrizes: i) representantes hindus e muçulmanos das duas províncias disputadas, Punjabe e Bengala, deveriam votar por fracionamento ou incorporação a um dos dois novos Estados, sendo que, havendo qualquer dissenso, ocorreria a partição; e ii) nos estados principescos os representantes deveriam escolher a qual dos novos Estados seriam incorporados.

Até 1937, estados periféricos como Butão, Nepal e Birmânia tiveram reconhecidas suas independências pelos próprios britânicos. Em 1947, Paquistão e Índia alcançaram a autodeterminação pela via da fragmentação do espaço regional, sendo que Punjabe e Bengala foram divididas por comissões mistas e os estados principescos escolheram autonomamente seus destinos. A maioria dos príncipes, incluindo muitos muçulmanos, aceitou o domínio da nova Índia. O Nawab de Bahawalpur, os líderes na fronteira noroeste e os Talpurs na província de Sind passaram para o domínio paquistanês. Somente os príncipes de dois estados permaneceram indecisos após 1947, ambos desejosos de algum grau de independência: Caxemira, estado poliglota de maioria muçulmana, mas com Marajá hindu; e Hyderabad, de maioria hindu, mas governada por Nizam muçulmano.

Segundo a fórmula anteriormente oferecida pela mediação britânica, os príncipes desses Estados deveriam escolher entre Índia e Paquistão, mas a disputa por espaços no Sul da Ásia seguiu lógica de segurança dos novos Estados formados. Tanto Hyderabad quanto o estado de Junagadh, cujo príncipe já havia manifestado seu desejo de união ao Paquistão, encontravam-se dentro dos limites territoriais da nova Índia, de modo que foram por esta assimilados sob a justificativa de que o princípio da autodeterminação era aplicável às populações locais de maioria hindu e não aos governantes muçulmanos. As províncias francesas e portuguesas no subcontinente tiveram o mesmo fim, sendo que aquelas foram cedidas pacificamente e estas foram anexadas pela força, ignorando decisões da Corte de Haia.

Foi a anexação do estado da Caxemira, contudo, que gerou a pior repercussão na interação entre as unidades do complexo de segurança do Sul da Ásia, porque foi quando o expansionismo indiano demonstrou-se claramente ilegítimo. Após as independências, a 
população muçulmana da Caxemira incentivou que tribos Pachtun de Punjabe migrassem para a província, com vistas a substituir o líder hindu, que, pressionado, decidiu pela incorporação à Índia. Em resposta, a Índia enviou aviões de combate para bombardear o avanço das tribos, enquanto que Jinnah, baseado na proximidade cultural e geográfica do Paquistão com a Caxemira, saiu em apoio das tribos, declarando a Primeira Guerra entre Índia e Paquistão.

Sob a mediação da ONU, o conflito teve fim com a assinatura de acordo de cessarfogo entre as partes, reconhecendo a Line of Control (LoC) como limite de contenção das atividades militares de cada Estado. A partir de então, a ONU passou a pressionar a Índia, exigindo que a população fosse consultada sobre a anexação, ao que a Índia reagiu obtendo declaração favorável à anexação por parte da assembleia local em 1956. Durante a década de 1960, a Caxemira teve parcela anexada pela China e foi novamente alvo de Guerra entre Índia e Paquistão, finalizada, sem mudanças territoriais, pela Declaração de Tashkent.

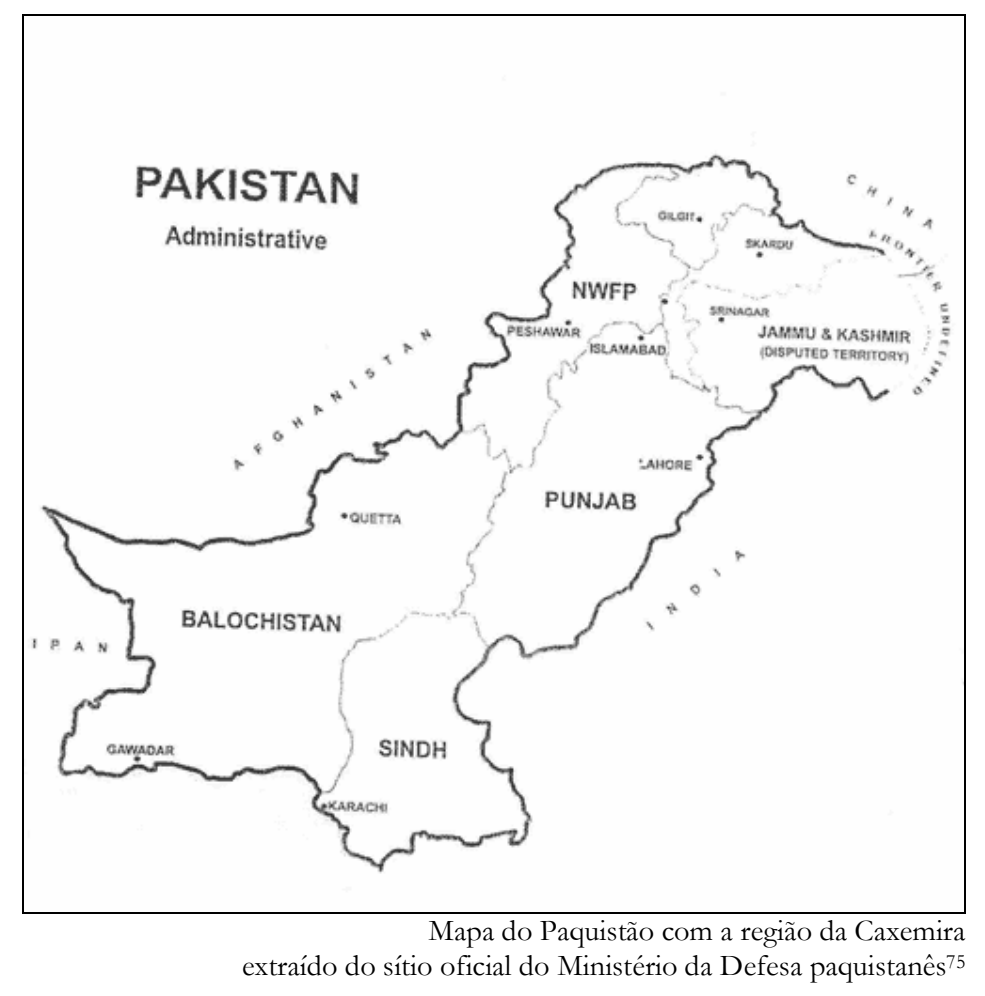

${ }^{75}<$ http:/ / www.pakistan.gov.pk/divisions /ContentInfo.jsp?DivID=7\&cPath=62_579\&ContentID=3718>, último acesso em 12/11/09 


\section{Características E OPERAÇÃo do CoMpleXo Regional}

\section{Eixo de Rivalidade: Índia-Paquistão}

A interação entre os dois Estados criados em 1947, Índia e Paquistão, constitui eixo de sustentação do complexo regional de segurança do Sul da Ásia. Em futuras sessões desta monografia, outras peças e fatores serão amalgamados a esse eixo central de modo a constituir complexo com escopo do subcontinente analisado na segunda parte. Após analisar isoladamente os vários componentes do complexo de segurança e verificar que funções cada um desempenha para a unidade e para a caracterização do todo, será possível compreendê-los como um conjunto de unidades interagindo conforme agenda regional determinada.

Para mapear a interação entre Índia e Paquistão é necessário ressaltar três aspectos estruturais, bem como suas consequências efetivas.

O primeiro aspecto estrutural na relação entre Índia e Paquistão é a complexa rede de vinculação identitária que, constituída sobre vieses de diferença civilizacional, interage, e por vezes sobrepõe-se, às relações estatais. Como foi apresentado, embora Índia e Paquistão sejam espécies políticas derivadas do mesmo espaço regional, diferenças culturais perduraram sob a ação do tempo e culminaram na criação de dois Estados distintos. Durante o grande período entre o Império Mogul e a ocasião histórica que deu origem a Índia e Paquistão, elementos de conflitividade foram adicionados a impressões e expectativas por parte de cada cultura sobre as outras localizadas no Sul da Ásia. A despeito dessas diferenças, há diversidade identitária própria e significativos exemplos de interação pacífica em cada unidade política.

Ambas as maneiras de interpretar os efeitos de diferenças culturais são ora amenizadas, ora intensificadas pela lógica de interesse racional de cada Estado. Entretanto, a forma mais frequente de manifestação da influência dessas diferenças ocorre por meio de criação de grupos de identidade infra e transnacionais, com verificado uso de práticas terroristas. Entre Índia e Paquistão, a zona que apresenta maior ocorrência de atentados terroristas é também a que mais sofreu com a partição, descendo da Caxemira até Mumbai. Acusações indianas de comprometimento do governo paquistanês com grupos responsáveis por atentados terroristas representam constante vetor de tensionamento na relação indo-paquistanesa.

O segundo aspecto estrutural é a disputa territorial pela Caxemira. Como foi apresentado na seção anterior, a anexação indiana de partes da Caxemira é fato simbólico no 
cisma da partição injusta e ilegítima que perdura até hoje em arquétipos de nacionalidade paquistanesa. A reconquista da Caxemira foi, ao longo de toda a história do Paquistão, objetivo militar com poder de elevação de sentimento de identidade nacional. O cisma territorial da Caxemira é, dessa forma, mantido vivo pelo exército paquistanês, que é historicamente a burocracia mais poderosa do país ${ }^{76}$.

Em 1947, mas também em 1965, Índia e Paquistão travaram guerras pelo controle territorial da Caxemira, que foi razão de intensa movimentação nos foros da ONU. Em cada nova crise ou pequeno desentendimento que emerge nas relações entre Índia e Paquistão, o cisma da Caxemira é exaltado, de modo a assumir posição central na perpetuação de cultura de rivalidade entre os dois países.

Um último aspecto estrutural para a interação indo-paquistanesa que deve ser ressaltado é o engajamento central desses Estados em dilema de segurança com dimensão regional. Um dos efeitos da instituição, nas burocracias de cada Estado, de preferência por políticas erigidas sob a égide da lógica estadocêntrica foi o engajamento de Índia e Paquistão em corrida armamentista, na qual há também participação da China.

A corrida armamentista desenvolveu-se para estado de dissuasão mútua ao longo da década de 1970, devido ao desenvolvimento de ogivas nucleares por ambos os países e pela China, peça necessária para constituição do dilema de segurança regional. Desde então, a dissuasão vem sendo assegurada por meio de inovações tecnológicas nos arsenais militares e testes de mísseis balísticos, com o objetivo de demonstrar aperfeiçoamentos no alcance, efetividade e flexibilidade face à possibilidade de guerra nuclear.

Como consequência desses aspectos estruturais, a interação indo-paquistanesa é caracterizada por movimento cíclico que combina historicamente episódios de tensão e distensão. Diversas guerras, crises nucleares e incontáveis desentendimentos políticos configuram saldo de pouco mais de sessenta anos de interação autônoma dos países do eixo de rivalidade no Sul da Ásia.

Além das citadas guerras pelo controle da região da Caxemira (1947 e 1965), Índia e Paquistão travaram ainda uma terceira em virtude da secessão do Paquistão Oriental (atual Bangladesh), em 1971. A governabilidade do Estado paquistanês até a década de 1970 esteve extremamente prejudicada devido à quebra de continuidade territorial. Com a morte de Jinnah menos de um ano após a independência de 1947, nenhum político paquistanês foi capaz de

\footnotetext{
${ }^{76}$ RIZVI, Hasan-Askari. Military, State and Society in Pakistan. 2000
} 
governar legitimamente o país, cujo ambiente político tornou-se recheado de desconfianças de uma ilha territorial com relação à outra.

Não obstante os benefícios estratégicos que a secessão do Paquistão Oriental rendeu à Índia, fixando a balança de poder bilateral drasticamente a seu favor, a Índia não aderiu efetivamente à guerra, se não em retaliação a ataque paquistanês. Em 14 dias de combate efetivo, a Índia demonstrou superioridade em suas forças naval e aeronáutica, evitando o desenvolvimento de combate terrestre e tornando claras as diferenças de capacidade entre os dois países rivais que desde então não se engajaram em nova guerra declarada.

De 1975 em diante, a despeito da ausência de conflito efetivo entre Índia e Paquistão, desenvolveu-se na região um sistema de paz armada, no qual ameaças - ora vedadas, ora demonstradas - resultam na necessidade de constante renovação de dissuasão imposta por cada poder regional ao outro. A operação desse sistema de dissuasão envolve Índia, Paquistão, China e potências externas, de modo que os demais atores regionais, inclusive Bangladesh, esforçam-se para não se comprometer com as dinâmicas do eixo de rivalidade regional.

A partir de 1974, quando a Índia se destacou na cena internacional por se tornar o primeiro Estado a adquirir tecnologia de armamentos nucleares afora as potências do P-5, o fator nuclear incipiente desenvolveu-se até se tornar peça central na caracterização do complexo regional. Em virtude de período turbulento iniciado com ameaça e dissuasão nuclear em 1987 - tensionada pela Operação Brasstacks ${ }^{77}$, Índia e Paquistão passaram a tentar, sem sucesso, evitar proliferação nuclear na região. A não adesão desses Estados ao regime de nãoproliferação e a insistência paquistanesa em aceder à tecnologia de armamentos nucleares levou os países a crise permanente durante toda a década de 1990.

Em 1998, após um ano de esforço, por parte dos primeiros ministros dos dois países, para debater meios de cooperação econômica e de segurança mútua, a nuclearização do CRS do Sul da Ásia tornou-se completa mediante o primeiro teste nuclear do Paquistão, quando a conjuntura regional enfrentava período crítico. Em episódio que ficou conhecido como a Crise de Maio, o Paquistão retaliou múltiplos testes nucleares indianos realizados no estado do Rajastão lançando outros de seu próprio arsenal. Após intensa movimentação diplomática de atores externos à região, em fevereiro de 1999, os países acordaram no Memorando de Lahore, segundo o qual se comprometiam a notificar novos testes nucleares com antecedência.

\footnotetext{
${ }^{77}$ Em 1987, a Índia mobilizou o maior contingente militar desde a Guerra Mundial II para realizar treinamento de rotina de seu exército próximo à fronteira com o Paquistão.
} 
Entretanto, a paz de Lahore durou pouco, uma vez que, no mesmo ano, a Caxemira reassumiu sua posição de perene motivação de conflitividade no sul da Ásia. Em episódio que ficou conhecido como a Crise de Kargil, pela primeira vez dois países com capacidade nuclear se enfrentaram em campo de batalha. Três meses depois da declaração conjunta em Lahore, a Índia realizou exercícios com aviões de batalha na região da Caxemira e o exército paquistanês decidiu reocupar os postos de defesa na LoC (Line of Control).

Respaldado na força da dissuasão nuclear, o Paquistão aproveitou para ocupar alguns postos também em partes do território sob controle indiano. Durante a Crise de Kargil, o uso de armas nucleares em combate convencional contra a Índia foi tratado como possibilidade efetiva por parte do Paquistão, uma vez que este havia desenvolvido, com o auxílio de cooperação chinesa, tecnologia para uso de "armamento nuclear tático" (TNW) ${ }^{78}$. O episódio causou péssima repercussão na comunidade internacional e levando ao surgimento de estudos apontando fontes de instabilidade na dissuasão nuclear do Sul da Ásia, considerada menos estável do que o caso original da Guerra Fria entre EUA e Rússia ${ }^{79}$.

Ainda durante a Crise de Kargil, houve severas acusações de envolvimento do governo paquistanês com o grupo terrorista Lashkar-e-Toiba, de modo que a população indiana e a comunidade internacional passaram a temer uma Jihad nuclear no Sul da Ásia. Como consequência da crise, Nova Delhi recusou-se a retomar a agenda de aproximação com Islamabad e teve início um período de grande instabilidade interna no Paquistão que resultou no golpe de Estado do militar, liderado por Pervez Musharraf.

Sob maior influência dos EUA, o governo de Musharraf buscou retomar as dinâmicas de aproximação com Nova Delhi, mas novas negociações só ocorreram em 2004. Neste ano, a diplomacia russa e a Gazprom passaram a apoiar a criação de projeto de cooperação energética entre os países do Sul da Ásia que consistia na construção de gasoduto iraniano que visava abastecer a Índia e o Paquistão. Nessa conjuntura, em encontro dos líderes políticos dos dois países em 2005, foram adotadas medidas concretas de cooperação visando adensamento do comércio bilateral e maior fluxo de pessoas, de modo que a aproximação iniciada em Lahore tornou-se algo bastante próximo de um processo de paz.

\footnotetext{
${ }^{78}$ Tactical Nuclear Weapons (TNW) são armas nucleares de potência menor do que 5 kilotons. Sua potência reduzida e a ênfase na flexibilidade permitiriam, teoricamente, o manuseio dessa tecnologia em combate sem ameaça à população civil.

79 MACHADO, A. A. S. Testes Balísticos no Sul da Ásia: A relação Índia-Paquistão. 2008.
} 
Ainda não é possível afirmar se o projeto de construção de paz avançará para além de seu escopo conjuntural, uma vez que as ações políticas posteriores vieram no sentido mais de contrariar que de contribuir para o processo. À época se explicava o fracasso de coordenação política em virtude de fatores na política interna dos países: de um lado, o partido de situação no executivo da Índia não tinha maioria no parlamento, enfrentando crise de governabilidade; de outro, tanto o governo de Musharraf, quanto o próprio Estado paquistanês enfrentaram crise de enfraquecimento institucional. No auge da política de defesa de Musharraf, o orçamento militar nacional chegou a corresponder a 40\% dos gastos governamentais, e ainda assim o governo não foi capaz de combater atores transnacionais atuando em seu território, conjuntura que lançou o Paquistão em dinâmica de ameaça de falência estatal.

A partir da Crise de Kargil, surgiu como subproduto da dissuasão nuclear, uma nova prática de testes de mísseis balísticos com capacidade nuclear. Esse tipo de interação faz uso de mísseis balísticos sem carga com o intuito de demonstrar aumento das capacidades de alcance e flexibilidade nos veículos de armamento nuclear desenvolvidos por Índia e Paquistão. A instituição dessa prática, em face da sabida condição nuclear dos países rivais, mantém os efeitos da dissuasão tradicional com testes nucleares, embora produza menores custos políticos na comunidade internacional.

Os testes de balísticos constituem, desde 2002, característica permanente do CRS, uma vez que têm frequência inalterada pela agenda de cooperação indo-paquistanesa. Quinze dias antes do encontro interministerial para levar adiante o processo de paz entre os países, em maio de 2008, Paquistão e Índia saudaram a tradição de rivalidade com sequência de hostilidades e testes balísticos. Um mês depois do anúncio de negociações para cooperação nuclear entre Índia e EUA em 2006, o qual o Paquistão considerou discriminatório, houve atentado terrorista em Mumbai e a polícia local sugeriu participação do serviço secreto paquistanês, a ISI (Inter-Services Intelligence Agency), na realização dos ataques. Durante os meses subsequentes, a periodicidade dos testes foi intensificada.

A Crise de Mumbai de 2006 é representativa de ainda outro entrave na distensão das relações bilaterais entre Índia e Paquistão. Desde a Crise de Kargil, há recorrente ação de grupos terroristas com foco nas regiões islâmicas indianas que fazem fronteira com o Paquistão e consequente acusação, por parte da Índia, de comprometimento das instituições oficiais do governo paquistanês com os grupos terroristas. 
$\mathrm{Na}$ transição de 2008 para 2009, foram superadas as circunstâncias internas que forçaram Índia e Paquistão a abdicar da aproximação política derivada do projeto do gasoduto da paz. Em setembro de 2008, o governo de Musharraf foi destituído e cedeu lugar a novo governo civil, liderado por Asif Ali Zardari. Em maio de 2009, eleições para o Parlamento indiano levaram a grande aumento de governabilidade para o Partido do Congresso, que já estava na situação em 2006. A despeito disso, pouca coisa mudou nas dinâmicas de cooperação e de conflito institucionalizadas no eixo de rivalidade do Sul da Ásia e o novo governo paquistanês já desperdiçou a primeira chance de intensificar os compromissos de cooperação, quando os responsáveis por novo ataque terrorista a Mumbai em dezembro de 2008 foram absolvidos pelo judiciário paquistanês ${ }^{80}$.

\section{China: o terceiro pilar do sistema}

Desde a guerra de 1962, Paquistão e China engajaram-se em processo de aproximação que se prolongou por toda a história do complexo regional. Durante a guerra da URSS no Afeganistão, a China, em cooperação com a CIA e com o Paquistão, passou a auxiliar a resistência Muhajideen, inclusive com programas de cooperação militar e venda de armas.

No imediato pós-Guerra Fria, a China conseguiu isolar a Índia no contexto regional, recrutando o apoio dos pequenos países pressionados entre os dois gigantes e fortalecendo a tradicional aliança com o Paquistão, que contou com apoio temporário dos EUA. Em 2003, o exército paquistanês contribuiu para a pacificação da província chinesa Xinjiang, que havia se sublevado, e em 2004 China e Paquistão empreenderam exercícios militares conjuntos de contraterrorismo na mesma província. A primeira visita de Zardari, assim que eleito presidente do Paquistão, foi à China e em ambos os discursos que direcionou para Assembleia Geral da ONU (AGNU) em 2008 e 2009, o presidente mencionou o interesse paquistanês em adensar laços políticos e econômicos com a China.

A importância da China no complexo de segurança do Sul da Ásia é tamanha que as mais importantes dinâmicas de interação não podem ser compreendidas sem a participação chinesa, mesmo aquelas prementes no eixo de rivalidade. A China exerceu papel central na nuclearização do Sul da Ásia, seja servindo como ameaça motriz ao programa nuclear indiano, seja desenvolvendo inúmeros programas de cooperação com o Paquistão em itens de

\footnotetext{
80 The Economist print edition. Sharm Offensive, 16 de julho de 2009. Disponível em $<$ http://www.economist.com/world/asia/displaystory.cfm?story_id=E1_TQDVNNPN>
} 
tecnologia de uso dual. As três plantas nucleares instaladas no Paquistão e a tecnologia dos principais itens do arsenal balístico paquistanês foram construídas com auxílio da China ${ }^{81}$.

Os vínculos de amizade entre China e Paquistão derivam da inimizade e da desconfiança que ambos compartilham com relação à Índia. As origens fundamentando a rivalidade sino-indiana derivam em grande medida da herança de políticas do Raj Britânico sobre o subcontinente. Em 1949, quando o regime comunista consolidou-se na China, este passou a reivindicar novas negociações de fronteira com o Estado indiano recém-criado, que havia herdado hegemonia sobre os pequenos Estados entre Índia e China e sobre o Tibete. A Índia, por sua vez, satisfeita com o status quo herdado, esforçou-se para que o Tibete não viesse a ser incorporado ao novo Estado chinês e em 1951, o Tibete aceitou renovação da relação de suserania com a Índia em troca de autonomia regional.

Em 1954, a China conseguiu fazer com que a Índia reconhecesse sua soberania sobre o Tibete por via de tratado. Nessa ocasião, Índia e China fixaram os Panchsheel, ou Cinco Princípios de Boa Convivência ${ }^{82}$, e todas as agências políticas especiais britânicas foram desativadas. Entre 1954 e 1962, China e Índia mantiveram excelentes relações com base nos Panchsheel, de modo que o período é considerado como a "Lua de Mel" entre China e Índia ${ }^{83}$. O embaixador chinês na Índia argumentou em 2005 que os Panchsheel continuavam em vigor inclusive na formulação de política externa ${ }^{84}$, o que de fato consta no livro branco publicado pelo Ministério de Defesa chinês em $2008^{85}$.

O único inconveniente que continuou ativo entre 1954 e 1962 foi a tentativa indiana de exercer pressão sobre a China para que esta mantivesse o Tibete sob regime de relativa autonomia. Em 1959, teve início sublevação popular do povo Tibeteano, desejoso de maior autonomia. Nessa ocasião, o governo indiano adotou política de apoio mais aberto ao povo Tibeteano, recebendo exilados políticos. Quando o Dalai Lama chegou à Índia pedindo asilo e santuário político, a população indiana exerceu enorme pressão sobre o governo, fazendo-o acolher o líder espiritual budista e permitir o estabelecimento de um "Governo Tibeteano em Exílio" na cidade indiana de Dharamsala, em 1960.

\footnotetext{
${ }^{81}$ MALIK, Mohan. China and the Nuclear Non-Proliferation Regime. 2000

${ }^{82}$ Em resumo, os Panchsheel constituiam grandes princípios similares ao da não-intervenção nos assuntos internos, respeito à soberania, e necessidade de benefício mútuo na solução de contendas.

${ }^{83}$ RANDOL, Shaun. How to Approach the Elephant:, 2008

${ }^{84}$ Discurso de Yuxi Sun durante Simpósio sobre Chíndia em Nova Delhi em 2005. Disponível em

<http://www.chinaembassy.org/in/eng/dsjj/dashijianghua/t21494.htm>, último acesso em 12/09/09.

${ }^{85}$ Disponível em < http://www.gov.cn/english/official/2009-01/20/content_1210227_15.htm>
} 
Em resposta, a China argumentou que a Índia havia quebrado os cinco princípios de convivência pacífica e ordenou que suas tropas marchassem sobre o subcontinente, expandindo territorialmente o império socialista chinês sobre o norte indiano. A nordeste, as tropas chinesas avançaram para além do Brahmaputra até Longju, nas Montanhas do estado de Assam. A noroeste, a China adentrou a Índia por Aksai Chin - a única fração da fronteira que não fora demarcada pelo o Raj britânico - e anexou porção territorial até o principado budista de Ladakh na Caxemira. O final da Guerra de 1962 fixou a Line of Actual Control (LAC), como fronteira de facto entre China e Índia, que até então não foi convencionada e não seria discutida até antes de 1993.

Enquanto a Índia planejava maneiras belicosas de recuperar o território perdido, China e Paquistão iniciaram processos de negociação de fronteiras na Caxemira. Argumentando que o controle da Caxemira era vital seu sistema fluvial, o Paquistão ainda arriscou pedir à China que cedesse a parte do território anexado na Caxemira e o ajudasse a recuperar o restante contra a Índia. Como se sabe, o Paquistão conseguiu somente promessa informal de aliança, que lhe rendeu apoio diplomático e fornecimento de armas durante a guerra de 1971.

Durante a Guerra Fria, o Paquistão tornou-se peça central para a política chinesa para o Sul da Ásia e também como plataforma para alçar-se em direção ao Oriente Médio. Nas palavras do General Xiong Guangkai, uma das figuras mais proeminentes do exército chinês, o Paquistão é o "Israel da China" ${ }^{86}$. A Índia, por outro lado, passou a ser considerada a maior ameaça ao sul do país, com poder de desestabilizar Tibete e Xinjiang. À oposição entre Índia e China foi ainda incorporado o desenvolvimento das relações de ambos os países com a URSS, constituindo outro sistema de rivalidades contingenciadas entre os gigantes asiáticos.

Desde o final da Guerra Fria, a política de segurança indiana com relação à China passou por fases intercaladas de tensão e distensão. Entre 1989 e 1993, houve período de esforços unilaterais de aproximação indiana, durante o qual a China ensejou aproveitar-se do isolamento da Índia no contexto do imediato pós-Guerra Fria para consolidar posição de supremacia no Sul da Ásia. Em 1992, houve um episódio simbólico para essa fase quando a China ordenou a realização de teste nuclear durante visita de Venkataraman, então presidente indiano, a Pequim ${ }^{87}$.

\footnotetext{
${ }^{86}$ PANT, N.K. Is China Wanting to Have an Indo-Pak War?, 2002

${ }^{87}$ Ver: <http://news.indiamart.com/news-analysis/agni-ii-test-step-to-6403.html>. Último acesso em 12/11/09
} 
Entre 1993 e 1998, as relações bilaterais deram um importante salto rumo à estabilização, após a aceitação de proposta indiana para dessecuritizar antigas disputas lindeiras. Em 1993, China e Índia assinaram acordo para manutenção da paz e tranquilidade na LAC ${ }^{88}$. Em 1996, os países chegaram a novo acordo que visava desenvolver medidas de construção de confiança no campo militar ao longo da $\mathrm{LAC}^{89}$.

Durante a Crise de Kargil, entre 1998 e 2002, a China retrocedeu drasticamente em sua posição e passou a apoiar militar e diplomaticamente a ofensiva paquistanesa. Entre 2001 e 2002, o então presidente Musharraf fez três visitas à China e conseguiu declaração de apoio chinês em ocasião de guerra contra a Índia, além de acordo de cooperação militar. A diplomacia chinesa também teve bastante movimentação em favor do Paquistão, mobilizando a neutralidade da Rússia na hipótese de guerra e passando a defender o argumento de que as acusações do governo indiano de vínculos entre o governo paquistanês e grupos terroristas em atuação na Caxemira eram apenas manobra geoestratégica para desmantelar a tradicional parceria entre EUA e Paquistão.

Findada a Crise de Kargil e enfraquecidos seus desdobramentos de hostilidade na região, intensificou-se por volta de 2003 e 2004 a agenda comercial da Chíndia ${ }^{90}$. Em declarações conjuntas assinadas em 2003 e 2006, China e Índia reconheceram o mútuo benefício econômico advindo da paz regional e comprometeram-se em realizar reuniões de cúpula para discutir pontos de defesa ${ }^{91}$. No mesmo ano, por outro lado, o governo paquistanês propôs a Nova Delhi que ambos abrissem mão de seus arsenais nucleares, mas a Índia rejeitou a proposta defendendo que seu arsenal nuclear não visava exclusivamente ao Paquistão.

A conjuntura atual revela-se nebulosa para precisar com absoluta certeza os aspectos qualitativos da relação entre Índia e China. Por um lado, a China mantém sua política de aumentar o comércio exterior com a comunidade internacional e com a própria Índia, de modo que estabilidade política interna e externa são salvaguardadas para atender a esse fim. Em 2007, quando a China se tornou o maior parceiro comercial da Índia, os países iniciaram

\footnotetext{
${ }^{88}$ Agreement on Maintenance of Peace and Tranquility along the Line of Actual Control in the Sino-Indian Border Áreas, disponível em < http://www.stimson.org/southasia/?sn=sa20020114287>, último acesso em $12 / 11 / 09$

${ }^{89}$ Agreement Between the Government of the Republic of India and the Government of the People's Republic of China on Confidence-Building Measures in the Military Field Along the Line of Actual Control in the IndiaChina Border Áreas, disponível em <http://www.stimson.org/southasia/?sn=sa20020114290>, último acesso em 12/11/09

${ }^{90}$ PINTO, P.A.P. China e Índia - Chindia (II): vasta estrutura econômica em construção, 2008.
} 
diálogo no campo da defesa, via trocas de delegações militares. Em 2008-09, realizaram dois encontros de alto nível, visando promover a "amizade e a paz, fundadas no princípio da equidade, segundo o qual cada um será sensível às ambições e preocupações do outro" ${ }^{92}$.

Por outro lado, fatores estruturais de inimizade histórica estão representados em uma série de medidas hostis impetradas pela China contra a segurança indiana. A partir de 2003, a China financiou a construção de porto civil e naval na província paquistanesa de Gwadar, garantindo acesso para sua marinha e, entre 2007 e 2008, ativou a navegação de submarinos com capacidade nuclear no Estreito de Malaca, renovando a tradicional disputa geoestratégica no Oceano Índico. Territorialmente, a China passou a emitir passaportes para a população da Caxemira e ordenou a remilitarização de bases com capacidades balística e nuclear ao longo da fronteira com a Índia em Xinjiang.

Ao que tudo indica, a política dual da China é fruto de divergências dentro de sua própria burocracia estatal ${ }^{93}$. O dualismo de posições na política doméstica se expressa em outros dualismos, de percepções contraditórias sobre a Índia e de objetivos de formulação de sua política para o Sul da Ásia.

\section{Periferia: Nepal, Butão, Sri Lanka, Bangladesh e Maldivas}

Não eram apenas a Caxemira e o Tibete os territórios quase-autônomos posicionados entre o Raj Britânico e os domínios de civilização chinesa. Além desses, outros dois Estados Principescos tiveram seus futuros condicionados pelas disputas entre os gigantes asiáticos que surgiram na segunda metade do século XX: Nepal e Butão. Ao contrário da Caxemira e do Tibete, Nepal e Butão mantiveram soberania formal e, juntamente com Sri Lanka, Maldivas e Bangladesh, conformam a periferia do CRS do Sul da Ásia.

O que mantém esses Estados unidos em um único grupo não são interesses compartilhados, como sugeririam teorias funcionalistas, mas, ao contrário, a diminuta capacidade de modificar a agenda de segurança regional ou de fazer com que seus interesses sejam alcançados. Apesar do deterem status de soberania formal, nem sempre os Estados da periferia do Sul da Ásia exerceram autonomia efetiva. Em uma pesquisa que seguisse ontologia

\footnotetext{
${ }^{91}$ Ver < http://www.expressindia.com/news/fullstory.php?newsid=22484> e < http://in.chinaembassy.org/eng/sgxw/2006en/t282045.htm>, último acesso em 11/11/09

${ }^{2}$ Notas oficiais disponíveis em <http://www.mfa.gov.cn/eng/wjb/zzjg/yzs/gjlb/2711/2713/>, último acesso em $12 / 11 / 09$

93 The Economist print Edition. Special Report on China and America. 22 de Outubro de 2009. Dispionível em < http://www.economist.com/specialreports/displaystory.cfm?story_id=14678555 >
} 
neorrealista, esses Estados não seriam entendidos como atores, mas sim como objetos do jogo de poder de China, Índia e Paquistão. Segundo a metodologia desta monografia, esses pequenos Estados serão importantes todas as vezes que, ativa ou passivamente, forem capazes de influenciar a agenda de segurança do complexo regional.

A maneira mais imediata como a periferia importa para a agenda de segurança regional é servindo de variável de ajuste para a disputa de influência dos Estados com maior capacidade. Nepal e Butão, premidos ao Himalaia entre Índia e China, foram historicamente disputados como zona de influência. Seguindo a política de fronteira herdada do Raj Britânico, a Índia recém-independente renovou, em 1949, acordo de cessão de direitos de representação internacional com o Estado de Butão, que só foi revisto em 2007 sem alterações de grande importância ${ }^{94}$. Em 1947 e em 1950, a Índia assinou acordos renovando o status de protetorado o território Siquim e, em 1950, logrou influenciar a política interna do Nepal, garantindo acordo para treinamento de suas tropas. Durante a "Lua de Mel" entre Índia e China, a independência do Nepal foi negociada sob a égide dos Panchsheel e, em 1961, um Tratado negociado em Pequim reconheceu a soberania do monte Everest ao Nepal.

A partir de 1962, quando as relações entre Índia e China se deterioraram, Butão e Nepal tornaram-se objetos da disputa por influência dos dois primeiros. Devido à presença das elevações do Himalaia na metade norte, mais próxima da China, Butão e Nepal têm relações menos intensas com a China. Vínculos culturais (em termos de religião budista e hindu) e econômicos também impulsionam os pequenos Estados a maior proximidade com a Índia. No entanto, por vezes a proximidade também levou a tensionamento nas relações, como é o caso dos grupos anti-indianos no sul de Butão, e outras vezes a China conseguiu expandir sua influência até essas regiões, como no imediato pós-Guerra Fria no Nepal.

O Sri Lanka é Estado de especial valor geoestratégico, pois sua posição é fundamental para adquirir influência militar sobre o Oceano Índico, que é objetivo dos gigantes regionais, Índia e China, assim como foi de EUA e URSS durante a Guerra Fria ${ }^{95}$. Por esse motivo, o contingente militar nacional superou a cifra de 200.000 homens em 2008.

Afora processos de segurança tradicional, a guerra civil que assolou o Sri Lanka entre 1983 e 2009 foi marcada por processos de securitização sócio-culturais e humanitários. Devido à convergência étnico-cultural existente entre a Índia peninsular e a militância rebelde, os

\footnotetext{
${ }^{94}$ Disponível em <http://www.mea.gov.in/pressrelease/2007/03/treaty.pdf>, último acesso em 12/11/09

${ }^{95}$ RAIS, R. B. The Indian Ocean and the Superpowers. 1986
} 
Tigres de Liberação do Tamil Eelam (LTTE), gerada pela expansão do Império Chola, o primeiro engajamento indiano na crise ocorreu em apoio ao segmento social sublevado, o que também esteve fundado em objetivos estratégicos ${ }^{96}$. Em 1987, Índia e Sri Lanka assinaram acordo em Colombo, contendo os termos de trégua entre as partes e possibilitando o envio de missão de paz indiana para a região. Em 2005 foi a vez da China se aproximar do Sri Lanka com acordos de cooperação militar e comércio de armamentos.

A partir de 2009, com o final da crise e desarmamento dos rebeldes, iniciou-se momento de securitização ambígua entre o humanitário e o sócio-cultural, quando a Índia passou a exigir do governo de Sri Lanka sua putativa responsabilidade de proteger os direitos humanos da população tâmil ${ }^{97}$.

A política externa de Bangladesh prezou pela neutralidade e afastamento das hostilidades regionais desde sua independência em 1971. Circunscrito em território indiano, o Bangladesh nutre boas relações com a Índia e com a China, em grande parte devido a intercâmbio comercial. Há grande margem de securitização econômica no discurso oficial ${ }^{98}$, o que fez com que o país demonstrasse protagonismo na formação da Associação Sul-Asiática para Cooperação Regional (SAARC) e da Iniciativa para Cooperação Multissetorial Econômica e Técnica da Bahia de Bengala (BIMSTEC). A partir de 2006, a China passou a exercer crescente influência sobre Bangladesh, manifesta em crescimento do comércio bilateral e em acordos de cooperação militar.

O fluxo de refugiados e a existência de movimentos anti-indianos atuantes no território do Bangladesh são pontos importantes em sua agenda de segurança bilateral com a Índia ${ }^{99}$. Os mesmos tipos de problemas derivados da gigantesca diversidade étnica no Sul da Ásia estão também presentes na agenda da Índia com outros países da periferia do Sul da Ásia. A crise dos refugiados de Butão é exemplificativa desse tipo de problema, uma vez que, entre 1991 e 1992, o Butão expulsou por volta de cem mil refugiados de origem nepalina, levando a crise sub-regional que só seria resolvida em 2007 quando os EUA incorporaram milhares de refugiados em seus próprios programas nacionais ${ }^{100}$. Ademais, grupos sociais com vinculação

\footnotetext{
96 TAMBIAH'S, Stanley Jeyeraja. Buddhism Betrayed? Religion, Politics, and Violence in Sri Lanka. 1992

${ }^{97}$ Declaração do Ministro de Assuntos Exteriores indiano sobre a situação no Sri Lanka. Disponível em: <http://www.mea.gov.in/speech/2009/04/22ss01.htm>, último acesso em 12/11/09

98 ABDUL, Muhammad M. East Asian Security: A Bangladesh Perspective, 2005

99 Troca de Notas entre o Senado e o Ministério de Assuntos Exteriores indianos. Disponível em: <http://www.mea.gov.in/parliament/rs/2009/02/26rs08.htm>, último acesso em 12/11/09

${ }^{100} \mathrm{Ver}<$ http:/ /www.unhcr.org/cgi-bin/texis/vtx/search?page=search\&docid=4aa641446\&query=bhutanese refugees $>$, último acesso em $12 / 11 / 09$
} 
identitária à causa anti-indiana existem em todos os Estados periféricos do sul da Ásia, em especial em Butão, Bangladesh, Sri Lanka e na província outrora autônoma da Caxemira.

A securitização de questões domésticas é outra dinâmica corrente nos países da periferia ${ }^{101}$. Uma vez que muitos desses países eram Estados Principescos, cuja autoridade política derivava de um único soberano, movimentos em prol da institucionalização de regimes democráticos tornaram-se constante nas histórias nacionais. Sob esse aspecto, a primeira década do século XXI é marcante porque tanto Nepal quanto Butão alcançaram maiores características de democracia.

Em 1989, a Índia restaurou o governo civil nas Ilhas Maldivas, por meio de engajamento militar. De pouca importância para outras agendas citadas, as Maldivas são as maiores responsáveis pela securitização da agenda ambiental na região. No subcontinente, há uma notável politização do problema de distribuição de água e controle fluvial, ${ }^{102}$ de modo que alguns chegam a considerar essa questão como aspecto de agenda de segurança. Todavia, a extrema vulnerabilidade das Maldivas à mudança climática devido à sua condição de mais baixo país do mundo fazem com que a agenda ambiental seja frequentemente securitizada em discursos oficiais com elevado apelo a interlocutores extrarregionais ${ }^{103}$.

\section{Afeganistão, Pachtunistão e Mianmar}

Afeganistão e Mianmar constituem os atuais limites do CRS do Sul da Ásia. Em inúmeras divisões regionais, o Afeganistão é considerado parte da Ásia Central e o Mianmar se excluiu do Sul da Ásia por seus vínculos institucionais com a ASEAN. Por outro lado, ambos são historicamente importantes para a formação e caracterização do complexo analisado. Incursões afegãs no subcontinente foram responsáveis pela criação de denso elo sociocultural com o espaço indiano, em especial com o Paquistão. O Afeganistão foi a barreira social que impediu o choque direto dos Impérios Russo e Britânico e que impediu o avanço da URSS. De sua parte, Mianmar constitui a perna das Índias para a Indochina e para o arquipélago de Malaca. Foi nessa plataforma de exportação de culturas indianas onde se frustrou o projeto nipônico de grande Ásia e por onde a China tenta se prolongar para o Índico.

\footnotetext{
${ }^{101} \mathrm{O}$ efeito dessas dinâmicas de securitização são similares ao que Adam Watson descreve como stasis política. Quando grupos de coletividade fracionam-se e polarizam-se acerca de dinâmicas domésticas, o conjunto não tem participação destacada em temas regionais.

102 WIRSING, Robert G. The Hydro Politics in South Asia: The domestic roots for inter-state river rivalry. 2007

${ }^{103}$ Discurso do Presidente das Maldivas. Disponível em

<http://www.presidencymaldives.gov.mv/4/?ref=1,6,2424>, último acesso em 12/11/09
} 
Se as circunstâncias levaram à fragmentação do enorme contingente populacional islâmico em toda Ásia Central, não foi possível impedir que o pan-islamismo perdurasse pelos tempos. Logo após a criação do Paquistão, Jinnah foi sensibilizado por essa identidade civilizacional e ordenou a retirada das tropas paquistanesas da zona das tribos Pachtun. Em decorrência disso, a fronteira entre Paquistão e Afeganistão é até hoje representada pelo traço ilusório da linha Durand, desenhado pelos britânicos em 1893. A linha Durand só existe em mapas, uma vez que a realidade geográfica dessa fronteira constitui emaranhado de montanhas e passagens subterrâneas que serve de abrigo para populações tribais e grupos terroristas.

Não fosse a resistência britânica às incursões dos Amir e a insistência seminal de Jinnah em criar um Paquistão secular, talvez houvesse hoje um grande Estado islâmico situado na cabeceira da Índia. Devido à existência de grupos populacionais transfronteiriços entre Paquistão e Afeganistão desde tempos imemoriais, o termo Pachtunistão foi cunhado para simbolizar a região ${ }^{104}$. Por volta de 1950, o Amir Mohammad Khan esforçou-se para mobilizar as tribos locais pela causa da autodeterminação, com o intuito de incorporar o Pachtunistão austral ao Afeganistão. Nem a fusão, nem a delimitação foram possíveis. Em 1947, a elite islâmica no espaço indiano recebeu direito de autodeterminação vinculado ao espaço de domínio colonial britânico.

Com a morte de Jinnah já em 1948, o Paquistão secular foi substituído por território sem Estado, no qual vários projetos de nacionalidade, regime político e ordenamento jurídico competiam para ordenar duas ilhas continentais islâmicas divididas pela Índia hindu. A única forma de garantir a unidade nessas circunstâncias foi a que de fato vingou: o Paquistão tornouse um Estado islâmico composto de fazendeiros e poder provincial. A instabilidade tornou-se a regra na história paquistanesa. Somente oito anos depois da independência, criou-se uma Constituição, que vigorou por dois anos até o primeiro golpe militar em 1958. Essa ruptura do regime democrático repetiu-se a cada duas décadas, com novos golpes em 1977 e 1999. O Paquistão passou por três guerras com a Índia, sendo que em 1971 houve a secessão do Paquistão Oriental, e o atual regime político data somente do final de 2008.

Entre 1978 e 1988, quando o General Zia-ul-Haq esteve no poder do Paquistão, o país passou por movimento de fortalecimento de ideias islâmicas e de instituições militares. Durante a Guerra entre a URSS e os Muhajideen no Afeganistão, o Paquistão auxiliou financeira e militarmente a militância rebelde. A ISI (Inter-Services Intelligence Agency) teve 
importante papel nesse contexto, fornecendo assistência técnico-militar. Da mesma maneira, quando em 1996 grupos Talibãs tomaram o poder no Afeganistão, só o fizeram em virtude de apóio financeiro fornecido pelo Paquistão.

Pouco mais de dez anos após a derrota dos soviéticos, o Paquistão foi reposicionado na linha de frente de outra guerra travada no Afeganistão: a Guerra contra o Terror. Novamente Paquistão e EUA uniram forças, mas dessa vez a militância afegã era o inimigo e não o aliado. Com o tempo, a comunidade internacional percebeu que, contrariamente às ações militares de EUA e Paquistão, os afegãos não eram constrangidos pelo desenho da linha Durand nos mapas políticos, migrando para o Paquistão sempre que desejavam sair do foco de combate.

Entre 2008 e 2009, a presença de terroristas, de migrantes afegãos e de grupos Talibãs entre o amálgama populacional das Áreas Tribais chamou a atenção para a vulnerabilidade da estratégia da Guerra contra o Terror e do próprio Estado paquistanês ${ }^{105}$. Em setembro, a incapacidade do Paquistão de exercer controle de facto do que um dia foi chamado de Pashtunistão, bem como do Waziristão do Sul ${ }^{106}$, ficou patente para a comunidade internacional. A proliferação de ataques terroristas no Paquistão e na Índia fez com que o tema assumisse importância crítica na agenda de segurança regional.

Se a noroeste o complexo de segurança é premido pela agenda de combate ao terrorismo, a sudeste é interrompido pela zona de alta institucionalização do ASEAN. Com a maior extensão territorial da Indochina, o Mianmar constitui elo entre o Sul e o Sudeste Asiáticos. Processos de securitização social, cultural e econômica levam à aproximação e ao isolamento entre as duas regiões.

A Indochina, assim como, de maneira um pouco menos expressiva, o Sudeste da Ásia, é extremamente influenciada pelo Budismo e pela cultura indiana ${ }^{107}$. Fluxos populacionais e manipulação de símbolos de vinculação identitária têm presença na agenda de segurança dos países com intersecção nessa zona de transição geográfica ${ }^{108}$. Na fronteira entre Índia e Mianmar, por exemplo, a atuação de grupos separatistas Katchins e Naga constitui outro exemplo de conflito de atores transnacionais contra autoridades oficiais.

\footnotetext{
104 TINKER, Hugh. Opt. cit, p.195

105 ZAGO, Evandro F. Noroeste Paquistanês em Crise: a Guerra contra o terror e o avanço do Talibã, 2009

106 The Economist. There they go again. Disponível em:

<http://www.economist.com/world/asia/displaystory.cfm?story_id=14710416>, ultimo acesso em 12/11/09

${ }^{107}$ KATZENSTEIN, Peter J. Why is there no NATO in Asia, 2002

108 DEEGALE, Mahinda. Norms of War in Theravada Buddhism, 2009
} 
Mianmar tem agenda de segurança bastante diversificada. Sua presença na Baía de Bengala levou Mianmar a disputar assiduamente a exploração de gás natural com Bangladesh ao longo de 2008. Desde 1962 sob sequência de regimes autoritários, em 2008 Mianmar também vivenciou momento de securitização interna (stasis política), mas os desdobramentos desse processo foram mais importantes no plano doméstico do que o Sul da Ásia, com pressão exercida pela ASEAN e pontual envolvimento da ONU e dos EUA ${ }^{109}$. Os EUA também têm agenda politizada com o país na questão de combate a narcóticos, uma vez que se suspeita que a produção e a exportação de ópio em Mianmar têm relação com o próprio exército do país ${ }^{110}$.

Mas a principal função que cumpre Mianmar para as dinâmicas do complexo de segurança do Sul da Ásia é justamente a intermediação geográfica de dois sistemas. Importante fonte de recursos naturais e destino de financiamento para Índia e China, Mianmar é visto por ambos os países como uma plataforma de acesso ao mercado da ASEAN. Para a Índia, Mianmar representa esfera de influência cultural e oportunidade para empreender sua look east policy. Em fevereiro de 2001, foi inaugurada a "Estrada da Amizade" por Ministro da Construção de Mianmar e Ministro dos Assuntos Exteriores da Índia, ligando materialmente Sul e Sudeste Asiáticos. Para a China, a ilha Coco de Mianmar é estratégica para consolidar a posição de sua marinha do Oceano Índico e boas relações com o país também são funcionais para o objetivo de fixar acordo de livre comércio com a ASEAN ${ }^{111}$. Apesar dessa disputa por influência, Mianmar mantém posição de relativa autonomia em face das dinâmicas de rivalidade no Sul da Ásia, consolidando seu perfil de fronteira entre os dois complexos.

\section{Atuação de Potências Externas}

As potências externas com marcada influência e atuação no complexo de segurança do Sul da Ásia são a Rússia e os Estados Unidos da América. A partir da segunda metade do século XX, quando a Europa já havia sido dividida em zonas de influência dos dois sistemas socioeconômicos liderados por EUA e URSS, o contorno asiático tornou-se região crítica para a defesa dos interesses das grandes potências. No Leste Asiático, o Ocidente havia consolidado uma parceria estratégica com o Japão e, no Sudeste, havia confiança no alinhamento de ex-

\footnotetext{
${ }^{109}$ BANDEIRA, Heloíza F. Mianmar e sua Contagem Regressiva para uma Suposta Transição de Regime, 2008

110 The Economist. Opium in the Golden Triangle. Disponível em:

$<$ http://www.economist.com/world/asia/displaystory.cfm?story_id=E1_TPPPDJTN\&source=login_payBarrier

$>$, ultimo acesso em 12/11/09

111 SHEE, Poon Kim. The Political Economy of China-Myanmar Relations: Strategic and Economic Dimensions. 2002
} 
colônias, principalmente aquelas com participação na Commonwealth. Apenas nas décadas de 1960 e 1970, com a guerra sino-indiana e com desentendimentos entre China e URSS, que foi definida a inserção do Sul da Ásia no sistema da Guerra Fria. No Sul da Ásia houve um processo no qual tanto as potências regionais se adaptaram à lógica da Guerra Fria, como também as superpotências tiveram de jogar conforme a polarização já existente na região. $\mathrm{O}$ mesmo padrão foi aplicado na redefinição da polarização que sucedeu o fim da Guerra Fria em 1990, em conjuntura que gradualmente atesta maior protagonismo da China na política internacional.

O Reino Unido, que fora o principal ator externo até meados do século $\mathrm{XX}$, distanciou-se da região a partir da década de 1960, passando a exercer somente influência esporádica e desinteressada sobre as dinâmicas do CRS, na maior parte das vezes por intermédio de instituições internacionais de que faz parte. Quando Pervez Musharraf impetrou o último golpe de estado no Paquistão, em 1999, este foi banido da Commonwealth até 200809, quando voltou a adotar regime democrático. Em virtude de posições britânicas, a OTAN está envolvida em sua primeira operação fora da geografia europeia (no Afeganistão) e foi concedido à Índia status de parceiro estratégico da União Europeia, posto que um dos princípios de parceria assinalados consiste na promoção da não-proliferação nuclear.

A aproximação entre EUA e Paquistão já durante a década de 1950, a aliança tácita entre China e Paquistão a partir 1962, a cooperação entre EUA e China a partir da visita de Nixon em 1969 e a cooperação trilateral entre EUA, China e Paquistão para conter o avanço soviético no Afeganistão na década de 1980 constituem sequência de movimentos que tiveram efeito de isolar a Índia na polarização regional. Durante o governo de Indira Gandhi (19661980), período de delineamento da política de segurança indiana na Guerra Fria, as maiores ameaças para a segurança indiana pautavam-se em hipóteses de guerra contra a China, de modo que a única alternativa disponível segundo os cálculos estratégicos da Índia era a formação de aliança defensiva com a URSS.

O Paquistão e os EUA já haviam firmado acordo de cooperação nuclear em 1954, logo que iniciadas as negociações para a criação da CENTO, mas a Índia permaneceria absolutamente comprometida com o Movimento dos Não-Alinhados até meados da década seguinte $^{112}$. A partir de 1965, quando EUA e Reino Unido retiraram o apoio que haviam concedido à Índia durante a guerra de 1962, esta se tornou crescentemente dependente da 
aliança e da cooperação com a URSS para suprir suas necessidades de segurança. Em 1971, no contexto da terceira guerra indo-paquistanesa, Índia e URSS assinaram tratados de Paz, Amizade e Cooperação, oficializando o alinhamento em âmbito regional, o que é uma das causas da paz armada no Sul da Ásia até o fim da Guerra Fria.

Como se sabe, o programa nuclear indiano foi em grande medida uma reação à ameaça chinesa sobre a Índia, mas também à ameaça chinesa sobre a URSS. Do mesmo modo, a aproximação entre Paquistão e Ocidente foi responsável por conter o avanço soviético no Afeganistão, mas também por mitigar a pressão internacional sobre o programa nuclear paquistanês, uma vez que, durante a década 1970, houve efetivo apoio da França, por exemplo, para a consolidação do programa ${ }^{113}$.

O fim da Guerra Fria trouxe consequências significativas para a polarização do complexo regional. Variáveis estruturais do ordenamento sistêmico não foram capazes de sanar definitivamente as disputas regionais, mas o esboroamento do Império Soviético, os atentados de 11 de setembro e a ascensão da potência chinesa constituem desenvolvimentos importantes para caracterizar o novo perfil do Sul da Ásia.

Nessa nova conjuntura, a política externa norte-americana para o Sul da Ásia fundamenta-se em maior pragmatismo e conhecimento das dinâmicas de rivalidade regionais, evitando demonstrar preferência por qualquer dos pólos na rivalidade indo-paquistanesa, mas aproveitando-se de cada um deles para promoção de seus interesses na geopolítica asiática. A nova posição norte-americana não levou a isolamento total em face da rivalidade indopaquistanesa, mas os EUA passaram a beneficiar a ambos com projetos de cooperação militar.

A cooperação ente Índia e EUA na área militar fundou-se a partir da década de 1990 e cresceu vertiginosamente durante os primeiros anos do novo século. Exemplos de exercício militar conjunto no Alasca, transferência de tecnologia e de inteligência, bem com venda de armamentos, demonstram mudança significativa nas relações Índia-EUA no pós-Guerra Fria. As marinhas organizaram uma patrulha conjunta pelas águas do Índico em 2002 e, em 2006, devido à influência crescente da China no Estreito de Malaca ${ }^{114}$, mas os países estão em negociações para tornar o exercício mais frequente e regular.

Os EUA também incentivaram a aproximação da Índia a aliados tradicionais no circuito asiático ampliado. Desde 2004, a Índia ganhou acesso à compra de aeronaves restritas

112 SHAA, S.A.A. Russo-India Military-technical Cooperation, 2001

113 DITTMER, Lowell. South Asia's Nuclear Security Dilemma: India, Pakistan, and China, 2005. 
do programa israelense Phalcon Airborne Early Warning, com capacidade de monitorar atividades militares no interior do Paquistão e da China a partir do espaço aéreo indiano. Todavia, a Índia preza pelo não engajamento em disputas no Oriente Médio ${ }^{115}$, uma vez que o Irã lhe é estratégico por permitir o uso de bases militares em eventual guerra contra o Paquistão.

As negociações entre EUA, Japão, Índia, Austrália e os países da ASEAN são por vezes interpretadas como um possível projeto de aliança quadripartite em cerco à China ${ }^{116}$. Em outubro de 2008, quando o Primeiro Ministro do Japão visitou a Índia, os países assinaram uma declaração conjunta, que ressaltou, entre outros pontos de entendimento, a necessidade de garantir a segurança nas rotas marítimas e o objetivo de promover maior integração com os países do Sudeste Asiático, em especial com os países da ASEAN ${ }^{117}$. O movimento de integração entre os complexos da costa asiática também está presente em declaração conjunta entre Japão e Austrália de $2007^{118}$ e entre os objetivos da política de defesa indiana de 2008-09.

Em julho de 2006, os EUA anunciaram novo acordo para fornecimento de combustível nuclear para suprir necessidades energéticas da Índia sem oferecer o mesmo ao Paquistão, que alegou também padecer de problemas de escassez de energia. Afora a importância estratégica do interlocutor norte-americano, para o equilíbrio da polaridade regional, o acordo de 2006 não é proposta avessa ao Tratado de Não-Proliferação (TNP), uma vez que a Índia já negociava projetos de cooperação na área nuclear com Brasil e África do Sul desde a década de 1990.

Os atuais objetivos indianos em suas relações com os EUA derivam de sua busca por reconhecimento de novo status de poder no meio internacional. Além de ser o segundo país mais populoso do mundo e contar com um dos maiores territórios, a Índia tem assegurado elevado crescimento econômico desde a década de 1990 e constitui um dos maiores contribuintes de tropas para missões da ONU. Nos últimos anos, dois objetivos têm guiado a ação internacional indiana: ser reconhecida como potência nuclear; e estabelecer relações de parceria estratégica com os EUA. O acordo bilateral entre Índia e EUA para cooperação em energia nuclear com fins pacíficos trabalha com ambos os objetivos simultaneamente.

\footnotetext{
${ }^{114}$ LI, Li. India's Security Concept and its China Policy in the Post Cold War Era, 2008

115 Indian Ministry of Defense. Annual Defense Report, 2008-09.

116 NYE, J.J. A Glass Half Full, 2009

117 Joint Declaration on Security Cooperation between Japan and India. Disponível em < http://www.mofa.go.jp/region/asia-paci/india/pmv0810/joint_d.html >, acesso em 09/09/09

${ }^{118}$ Japan-Australia Joint Declaration on Security Copperation. Disponível em <

http://www.mofa.go.jp/region/asia-paci/australia/joint0703.html >, acesso em 09/09/09
} 
Se as relações entre Índia e EUA melhoraram no contexto pós-Guerra Fria, a tradicional parceria entre os EUA e o Paquistão passou por fase de retrocesso na década de 1990. Durante as crises de 1998 e de Kargil, os EUA prestaram uma enorme contribuição para a pacificação da disputa indo-paquistanesa. A insistência, por parte do Paquistão, em levar adiante seu projeto nuclear, o qual culminou com grande crise regional em 1998, fez com que sua parceria com os EUA esfriasse momentaneamente - o que ficou explícito com as sanções econômicas impostas pelos EUA na sequência da crise. Com os atentados de 11 de setembro, o Paquistão voltou à posição de aliado dos Estados Unidos na guerra contra o terrorismo e muitas sanções econômicas que haviam sido criadas foram suspensas.

Logo depois dos atentados de 2001, os EUA passaram a equilibrar projetos de cooperação militar entre os dois rivais do Sul da Ásia. Se em 2002 fizeram exercícios conjuntos com a marinha indiana, logo em seguida venderam caças F-16 com capacidade nuclear ao Paquistão. O acordo de cooperação em energia nuclear de 2006 foi um ponto de ruptura dessa estratégia de equidade e teve terríveis repercussões internamente no Paquistão, gerando inclusive maior hostilidade em sua relação com a Índia ${ }^{119}$. A Índia, de sua parte, aproveitou cada atentado terrorista em seu território para acusar o governo paquistanês de apoio aos terroristas ou "ineficiência proposital" em seu combate. Muitas das acusações indianas, como foi argumentado anteriormente, de fato estão fundadas em evidências factíveis.

Entre 2008 e 2009, o avanço dos grupos terroristas para dentro do território paquistanês ficou patente, uma vez que grupos Talibãs passaram a exercer controle de facto de áreas do território. Para a sociedade paquistanesa, ademais, a Guerra contra o Terror vem sendo compreendida como uma agenda estrangeira custeada com a vida de nacionais paquistaneses ${ }^{120}$. Entre os americanos, cresceu a impressão de que o Paquistão deixou de ser a linha de frente na Guerra contra o Terror para se transformar no próprio campo de batalha. Em março de 2009, os EUA modificaram sua política para o combate ao terrorismo no Sul da Ásia, visando combater os grupos terroristas alojados na fronteira entre Afeganistão e Paquistão com maior articulação regional. A despeito da crescente cooperação militar entre Índia e EUA, a estes foi negado o uso de bases militares no interior do território indiano.

\footnotetext{
119 MACHADO, A. A. S. Testes Balísticos no Sul da Ásia: A relação Índia-Paquistão. 2008

${ }^{120}$ Para interessante debate da sociedade civil paquistanesa sobre a Guerra contra o Terror, ver

$<$ http://www.defence.pk/forums/strategic-geopolitical-issues/12923-pak-us-relationship.html>, ultimo acesso em $12 / 11 / 09$
} 
A partir do início da Administração de Barack Obama, surgiram sinais de ruptura da política externa norte-americana para o Sul da Ásia. A prioridade que o novo governo conferiu às relações com a China, inclusive com alguns analistas falando na conformação de uma diarquia hegemônica (o G-2) no sistema internacional a partir de 2009, levou a distanciamento dos pontos de tensão regionais por parte dos EUA. Essa transformação está evidenciada principalmente em possível abstenção de representar a simpatia dos EUA pela Índia e pelo Tibete mediante entrevistas presidenciais. Os encontros de chefe de Estado da Índia e dos EUA sofreram redução significativa em contraste com a Administração de George Bush e o presidente Obama apenas recebeu Dalai Lama protocolar e rapidamente em 2010.

Com o esboroamento da URSS, o engajamento russo-soviético no CRS do Sul da Ásia retroagiu severamente já na década de 1990. A cooperação militar e o comércio de armas entre Índia e Rússia nunca foi interrompida, mas o papel que a Rússia desempenha no complexo de segurança atualmente é diminuto. Desde a dissolução da URSS, a presença mais marcante da Rússia para efeitos da região foi tentativa de mediar disputas entre Índia e Paquistão para viabilizar a criação do projeto do "gasoduto da paz". Em dezembro de 2008, após visita do Presidente Dmitry Medeved à Índia, Rússia e Índia efetivaram a continuação de sua parceria estratégica, por meio de um acordo de cooperação para construção de novas instalações nucleares com tecnologia russa no território indiano e outro permitindo compartilhamento de espaços aéreos. Em 2009, o diálogo foi reduzido, mas espera-se que este seja fortalecido conforme a economia russa se recupere da Crise Financeira. 


\section{ANÁlise FinAL \& CONCLUSÕES}

\section{Limites do CRS}

O objetivo destas últimas três seções é resumir as várias políticas e percepções trazidas ao longo do texto e organizá-las sob a perspectiva do Sul da Ásia como complexo de segurança. Partindo dos elementos de delimitação e caracterização de atores, interesses, expectativas, percepções e agendas políticas nas duas partes egressas, buscar-se-á uma discussão panorâmica sobre a geografia estudada. Observa-se que o estudo foi capaz de aprofundar o conhecimento sobre o Sul da Ásia como região, aperfeiçoando pontos existentes na literatura.

A primeira discussão necessária é justamente a dos limites do complexo regional de segurança. Agora que os diversos elementos de delimitação e caracterização do Sul da Ásia foram analisados, emergem duas perguntas imediatas: o espaço analisado faz sentido como complexo de segurança? Até onde se estende o CRS do Sul da Ásia e que países, ou partes de países estão vinculados à homogeneidade do sistema?

Em primeiro lugar, o conhecimento das interações em âmbito de segurança do Sul da Ásia permite afirmar que a região constitui espaço distinto de qualquer outro a seu redor ou mesmo no resto da superfície da Terra. A ênfase na interação geoestratégica, na dissuasão nuclear e na lógica de percepções de ameaça cruzada entre os três pilares do complexo China, Paquistão e Índia - não transborda para outras regiões vizinhas e só tem escala de reprodução em contextos específicos do panorama sistêmico. Os países periféricos têm suas demandas de segurança praticamente ignoradas para efeitos de conformação da agenda de segurança regional e são muitas vezes incorporados à interação de rivalidade dos três grandes. O complexo é, portanto, bem caracterizado com relação à homogeneidade interior e heterogeneidade exterior.

De acordo com os critérios definidos por Buzan e Waever, a homogeneidade e a delimitação de um complexo de segurança deveriam estar pautadas no adensamento de interdependência securitária entre os atores de determinada região. Para satisfazer aos critérios definidos, Buzan e Waever demarcaram o CRS do Sul da Ásia como o conjunto dos seguintes países: Índia, Paquistão, Bangladesh, Sri Lanka, Nepal, Butão e Ilhas Maldivas. Afeganistão e Mianmar foram considerados Estados tampão, por estarem vinculados com interações em 
outros complexos subjacentes, sem serem completamente incorporados a qualquer deles. Quanto à China, apesar de sua importância para a caracterização do complexo, o método de Buzan e Waever não permitiu que esta fosse vinculada ao Sul da Ásia, uma vez que seu principal meio de interação é o Leste Asiático. ${ }^{121}$

Nesta monografia, os limites do Sul da Ásia são diferentes dos propostos por Buzan e Waever não porque houve grandes divergências na caracterização das interações regionais, mas sim por fundamentos metodológicos diferenciados. Uma vez que não houve a exigência preliminar em prefixar atores cada qual em um único complexo regional, foi possível analisar o Sul da Ásia contando com a participação fundamental de China, Afeganistão e Mianmar estes como territórios, aquela como ator.

A China exerce papel central para a polaridade e para a polarização no Sul da Ásia, de modo que a própria existência da região como complexo de segurança estaria comprometida sem a presença da China. O principal ator na definição de percepções e políticas de segurança da Índia é a China. Mesmo para Buzan e Waever, também os países periféricos do complexo não têm vínculo direto com o eixo de rivalidade indo-paquistanês ${ }^{122}$, ao passo que não é possível dizer o mesmo quando analisada a rivalidade entre China e Índia. Ignorada a interação da China no Leste Asiático, a China constitui ator basilar no Sul da Ásia, constituindo um dos pilares do complexo. É fato que para efeitos de demarcação geográfica não é adequado incluir todo o território chinês ao complexo de segurança, mas retirar a China do CRS levaria ao risco de fazê-lo fragmentar, uma vez que mesmo a periferia perderia vínculos com a região.

Quanto a Afeganistão e Mianmar, estes também têm sua importância reduzida pelo conceito de Estado tampão. No caso do Afeganistão, sua interação profunda e crescente com o Paquistão foi responsável por inundar a agenda de segurança do Sul da Ásia com a ameaça do terrorismo, principalmente a partir do final de 2008. Os efeitos da fragilidade e diversidade do Afeganistão não são de isolamento do Sul da Ásia em face da Ásia Central, mas sim de amalgamação dessas duas regiões. À medida que a agenda de combate ao terrorismo vem sendo incorporada pelo CRS do Sul da Ásia, também o Afeganistão vem se consolidando elemento constituinte do complexo. Na conjuntura atual, amputar o Estado afegão do Sul da Ásia significaria discutir também a exclusão do Paquistão, uma vez que há parcela territorial de tribos afegãs com intensa interação com o Sul da Ásia.

\footnotetext{
${ }^{121}$ BUZAN \& WAEVER. Opt cit.

122 Ibdem, p. 103.
} 
Quanto ao Mianmar, nesse caso a classificação de Estado tampão é mais evidente, mas novamente o Mianmar está mais próximo de um veículo de união do que de isolamento de dois complexos. Ademais, na medida em que a China é aceita como peça basilar do CRS, os vínculos de Mianmar com o Sul da Ásia crescem consideravelmente.

A demarcação dos limites do Sul da Ásia tem três pontos abertos. China e Mianmar correspondem a atores ficcionalmente unitários, com participação em múltiplas geografias e por isso constituem parte do Sul da Ásia conquanto atuem na região. O Afeganistão, devido à fragilidade de suas instituições estatais, pode ser fragmentado ou considerado como um espaço de vácuo de soberania, mas ainda assim os atores coletivos que detém livre acesso ao território paquistanês devem ser considerados para a constituição do Sul da Ásia.

Em cada um desses pontos abertos, há dinâmicas de constituição de complexos maiores em operação. Buzan e Waever analisaram essas forças com o que chamaram de supercomplexo asiático ${ }^{123}$. Desde uma perspectiva isolada do Sul da Ásia, qualquer conformação desse tipo deriva da ação de potências externas na internacionalização do complexo. De fato, a Índia (um ator interno ao complexo) adota políticas de aproximação com Irã, Rússia, ASEAN, Austrália e Japão, mas essas políticas não são suficientes para promover articulação interregional perene, muitas vezes porque são motivadas pela atuação dos EUA.

\section{A Agenda Regional de Segurança}

A partir da guerra indo-chinesa, quando foi consolidada a estrutura de polarização do CRS do Sul da Ásia, os poderes regionais passaram a concentrar-se na manutenção da polaridade, engajando-se em perene corrida armamentista. Durante a segunda metade do século XX, o orçamento militar regional cresceu com velocidade maior do que o PIB, passando de 1,8\% do produto regional em 1962, para mais de 3\% em $1989^{124}$.

Não há, por parte dos atores da região, qualquer tentativa de negociar conjuntamente as ameaças ou prioridades de segurança que afligem a abrangência do complexo regional. A agenda regional é um amálgama de posições e políticas articuladas individualmente com grande influência da lógica estatal e da segurança tradicional. Tentativas de solucionar essa agenda tradicional, no entanto, constam em raríssimos programas ou iniciativas de institucionalizar

\footnotetext{
${ }^{123}$ Ibdem, p. 99.

124 SRINIVAS, V.N. Trends in Defence Expenditure: India, China and Pakistan. 2006
} 
comportamentos em âmbito bi ou multilateral, sem que qualquer desses seja satisfatório para corresponder às demandas da região.

A frágil regulação bilateral pauta aspectos superficiais da relação entre Índia e Paquistão, com acordos firmados depois da primeira guerra da Caxemira e depois da crise de maio de 1998. A LoC, fronteira de facto na Caxemira, foi demarcada pelo acordo de cessar-fogo de 1948 e, embora seja constantemente desrespeitada por atores não-estatais, é minimamente reconhecida pelas partes como instituição que deve ser respeitada para manter a paz regional. Após 1998, o acordo de Lahore, com o qual Índia e Paquistão se comprometem a avisar-se mutuamente sobre testes nucleares é o marco do processo de paz bilateral que compromete os países esporadicamente. Com relação à China, os Panchsheel, definidos na década de 1950 e rompidos na de 1960, constituem o único apoio institucional para reger relações com a Índia. Outros tratados foram firmados, mas não ganharam força em termos de princípios.

A atuação de instituições internacionais externas à região é alternativa recorrente na mediação das disputas no Sul da Ásia. Logo que a Índia invadiu a Caxemira em 1947, a questão foi levada ao Conselho de Segurança da ONU, que decidiu que a contenda seria resolvida por plebiscito, fazendo com que o Paquistão ordenasse o recuo de suas tropas. A inflexibilidade da Índia nessa ocasião teve dois efeitos: Admiral Nimitz, administrador do plebiscito nomeado pela ONU, foi premido a resignar o posto; e iniciou-se a aproximação entre EUA e Paquistão.

Entre 1954, com a assinatura do Tratado de Manila, e 1977 os EUA lideraram o projeto de uma organização regional asiática, fundamentada em torno de aliança de segurança coletiva contra ameaça comunista, a SEATO (Southeast Asia Treaty Organization). À SEATO, foi adicionado um projeto irmão, a CENTO (Central Treaty Organization), constituída a partir do Tratado de Bagdá de 1955, por Irã, Iraque, Paquistão, Turquia e, informalmente, os EUA. Apesar do alinhamento paquistanês, ambos os instrumentos institucionais citados não estiveram preocupados com a agenda de segurança do Sul da Ásia, mas sim do nível sistêmico da Guerra Fria. Por duas vezes, em 1965 e 1971, o Paquistão tentou acionar seus aliados em conflitos com a Índia e por duas vezes o pleito lhe foi negado, de modo que o Paquistão abandonou a SEATO já em 1973 e a CENTO foi destituída em 1979.

Outras iniciativas de institucionalizar comportamentos relacionados à segurança internacional partindo da China chamaram atenção do Paquistão. Em 1996, criou-se a Organização de Cooperação de Xangai (SCO), voltada para o combate ao terrorismo na Ásia Central. Tanto o Paquistão como a Índia são membros observadores da SCO e quando a 
China negociou a criação da CSTO (Collective Security Treaty Organization), no escopo da Ásia Central, cogitou-se brevemente estender a capacidade de membro ao Paquistão, mas as circunstâncias (a assinatura ocorreu em 2001) e outros membros impuseram obstáculos.

Nenhuma dessas instâncias e tampouco outras iniciativas regionais, como é o caso da BINSTEC (Bay of Bengal Initiative for MultiSectoral Technical and Economic Cooperation), têm qualquer relevância para a agenda de segurança do Sul da Ásia. A única iniciativa regional que merece ser mencionada é a Associação Sul-Asiática para Cooperação Regional (SAARC), criada em 1985. Tradicionalmente, o foco da SAARC foi a promoção de intercâmbio comercial e as discussões políticas mais importantes, como a questão da Caxemira e a guerra civil no Sri Lanka, ocorreram à margem da organização ${ }^{125}$. Mesmo em âmbito comercial, a SAARC caminhava em ritmo lento, com sua primeira iniciativa de peso acontecendo em 1993, quando os Estados membros concordaram com o estabelecimento gradual de uma zona de livre comércio na região. Os primeiros acordos definindo metas nesse sentido ocorreram somente em 2006, quando foi estabelecido que seriam reduzidas as barreiras tarifárias em 20\% até 2007.

A partir do início do século XXI, no entanto, a SAARC tem ganhado força, especialmente como foro de discussão de questões securitizadas pelos países da periferia do complexo regional, as quais normalmente não eram levadas em consideração pela agenda de segurança regional. Em 2004, foi formulado um plano de ação para combate à pobreza na região. Em 2005, o tema da energia foi debatido em encontro interministerial, com consequências para o surgimento de futuros acordos bilaterais em cooperação energética. Em 2008, na reunião da SAARC em Sri Lanka, iniciativas regionais foram debatidas em termos de segurança alimentar.

A partir de 2004, quando o processo de paz entre Índia e Paquistão passou por bom momento, houve considerável fortalecimento da SAARC, incorporando-se a esta a possibilidade de discussão de um dos mais importantes temas na agenda de segurança regional: o combate ao terrorismo. Iniciativas efetivas voltadas ao combate ao terrorismo no Sul da Ásia são fundamentais para demonstrar em que medida a SAARC poderia se transformar em um instrumento importante na articulação de consensos e políticas regionais para o âmbito da segurança. Enquanto não há sinais palpáveis dessa mudança, que teria impactos na própria caracterização do complexo de segurança do Sul da Ásia, a SAARC deve continuar sendo

\footnotetext{
${ }^{125} \mathrm{Ver}<$ http://www.saarc-sec.org/main.php>, último acesso em 12/11/09
} 
interpretada como um mecanismo voltado para discussão da agenda de segurança da periferia, que os países da região acreditam ter menor grau de politização.

Ao contrário do que normalmente é esperado, o fim da Guerra Fria não representou marco de ruptura nos parâmetros estruturais da agenda de segurança no Sul da Ásia. Desde a perspectiva indiana, a dissolução da URSS em 1989 e a subsequente perda de relevância do movimento dos não-alinhados impulsionaram a Índia a intensificar sua busca por novos parceiros, uma vez que havia ficado isolada internacional e regionalmente.

Depois de breve momento em que a China logrou isolar a Índia, os EUA, ainda no governo Clinton, delinearam novas linhas de engajamento norte-americano no Sul da Ásia, optando por papel de mediador em um dos eixos de rivalidade (Índia e Paquistão) e de contingenciar as polaridades no outro (Índia-China). Independente do final da Guerra Fria, portanto, percepções de ameaças e securitizações cruzadas entre Índia e Paquistão e entre Índia e China continuam a fundamentar a homogeneidade do CRS do Sul da Ásia. A dissuasão nuclear, a prática de realizar e retaliar testes de mísseis balísticos e o armamentismo continuam correspondendo à maior parte das preocupações de segurança regional.

A agenda de segurança dos países da periferia, quando debatida em âmbito regional, passa a figurar como tópicos em estágio de politização e não de securitização. O mesmo podese falar de agendas bilaterais recorrentes na política externa indiana com enfoque em temas como migração e segurança social. Eventuais consequências da mudança climática podem exacerbar as percepções de ameaça para os tópicos da agenda da periferia, mas atualmente essa hipótese figura apenas no âmbito da especulação acadêmica.

Alguns analistas apontam para relativo abandono por parte de setores governamentais na Índia da lógica de segurança estatal nerhuniana em virtude de adoção de nova lógica de segurança da sociedade e segurança humana. Sob esse ponto de vista, o desenvolvimento econômico e social e a necessidade urgente de vinculação positiva à economia global seriam objetos securitizados já a partir do final da Guerra Fria. Esse tipo de discurso securitizante de fato emergiu na cena política indiana ${ }^{126}$, mas esteve contextualizado em políticas eleitorais e não surtiu maiores efeitos em termos de mobilização sociopolítica excepcional ${ }^{127}$. Afora isso, o

\footnotetext{
126 Indian National Congress, 'Security Agenda: Security, Defense and Foreign Policy’,Congress Sandesh, May 2004, <http://www.congresssandesh.com/may-2004/securityagenda.html>, acesso em 30/11/2009

${ }^{127}$ Mesmo o Partido do Congresso mantém agenda de securitização tradicional. Ver por exemplo, Manifesto de 2004, disponível em < http://www.congresssandesh.com/manifesto-2004/17.html>, acesso em 30/11/2009
} 
foco da política de segurança indiana ainda está sobre segurança tradicional, constituída sob a lógica estatal ${ }^{128}$.

O único tema que, por estar em marcha ascendente, pode assumir posição de proeminência na agenda de segurança do Sul da Ásia é o terrorismo e a atuação de grupos transnacionais. Para a China, que teme efeitos de transbordamento para seu território fragmentado por secessionismo étnico, o terrorismo no Sul da Ásia, em especial no Afeganistão, já era ponto prioritário, de modo que a própria sede da SCO foi instalada no Tadjiquistão. O Paquistão promove extenso programa de cooperação com os EUA para combate ao terrorismo, desde o governo de Musharraf. Com os novos atentados a Mumbai e à Embaixada Indiana em Cabul, ambos em 2008, o tema da estabilização do Afeganistão e do combate ao terrorismo foi adotado como prioridade na política de defesa indiana. Ações conjuntas ou articuladas não foram possíveis até então e tampouco há manifestação de vontade política para interação neste sentido. A Índia mantém acusações sobre a vinculação de grupos terroristas a agencias estatais paquistanesas e a China interpreta essas acusações em termos da balança de poder regional, como um golpe de discurso indiano para desmantelar a parceria entre EUA e Paquistão. Quando entendido como problema comum aos Estados da região, por outro lado, o tema do terrorismo permite articular consensos de maneira cooperativa, o que fica evidente diante de convenções da SAARC sobre o tema ${ }^{129}$.

\section{Cooperação e Conflito: cenários possíveis?}

"It is said that each conflict prepares the ground for the next one or every war contains the
seeds of another. The Afghan war of the 1980s against the Soviet occupation culminated in
the war on terrorism in 2001. Whether the war on terrorism will lead to another war or
clash of civilizations or a nuclear jihad in South Asia, only time will tell." "130

Para Buzan e Waever, cenários de cooperação e de conflito podem ser construídos a partir da própria caracterização de um complexo de segurança regional seguindo os seguintes parâmetros: i) estrutura anárquica; ii) estrutura de polaridade regional; iii) polarização entre os atores; e iv) a agenda de securitização regional ${ }^{131}$.

\footnotetext{
${ }^{128}$ Ver os Relatórios Anuais do Ministério de Defesa Indiano, publicados desde 1990, disponíveis em < http://mod.nic.in/reports/welcome.html>, acesso em 11/09/09

${ }_{129}$ Regional Convention on suppression of Terrorism; e Protocolo Adicional, disponíveis em <http://www.saarcsec.org/data/summit12/additionalprotocolterrorism.pdf> (último acesso 20 de novembro de 2009)

${ }^{130}$ MALIK, Mohan. The China factor in India-Pakistan conflict. 2003, p.45

131 Ver 4a seção da primeira parte.
} 
A partir desses critérios, os autores afirmaram que caracterização do CRS do Sul da Ásia passa por transição com o fim da Guerra Fria. Durante a Guerra Fria, o Sul da Ásia foi um complexo padrão (standard), com estrutura de poder bipolar e processos de securitização cruzados entre Índia e Paquistão. Após a Guerra Fria, o enfraquecimento relativo do Paquistão e o adensamento de interações entre complexos regionais estariam modificando as características do Sul da Ásia ${ }^{132}$. A polarização em ambos os casos seria de rivalidade, embora não haja referências explícitas para além do eixo Índia-Paquistão e a estrutura derive da estrutura sistêmica; sendo, portanto, anárquica.

De acordo com essa configuração, a tendência do complexo seria de perpetuar-se em conflito, embora a teoria de Buzan e Waever não permita ser taxativo. O que escapa da caracterização de operação do CRS e formulação de cenários, todavia, é a presença marcada da China e o alto grau de internacionalização da polaridade e da polarização do Sul da Ásia. Desde a criação do complexo, EUA e URSS-Rússia estiveram presentes no cômputo de cálculos estratégicos, na constituição de percepções e interesses e na conformação de fluxos de securitização.

Não é possível caracterizar a estrutura de poder no Sul da Ásia como bipolar durante a Guerra Fria ou como potencialmente unipolar no pós-Guerra Fria, porque em ambos os períodos a balança de poder esteve favorável à China ${ }^{133}$. A brutal diferença de poderes entre Índia e Paquistão ficou evidente desde a Guerra de 1947, o que foi reiterado em diversas ocasiões futuras. Não fosse a presença da China no Sul da Ásia, a estrutura do complexo seria unipolar desde 1947, mesmo considerando o engajamento relativo dos EUA a partir de 1954.

Além disso, as potências externas sempre atuaram no Sul da Ásia de modo a equilibrar a equação de forças regionais, considerando-se neste caso também o pólo hegemônico chinês. Em 1962, EUA e Reino Unido deram suporte à Índia na guerra contra a China ao passo que retiraram o apoio na guerra contra o Paquistão de 1965. No contexto pós-Guerra Fria, quando o colapso da URSS flexibilizou a polarização sistêmica, os EUA passaram a agir de maneira neutra, mediando a rivalidade indo-paquistanesa, mas subsidiando militar e simbolicamente a Índia para contingenciar a ascensão da China.

\footnotetext{
132 BUZAN \& WAEVER. Opt cit.

133 SRINIVAS, V.N. Trends in Defence Expenditure: India, China and Pakistan, 2006
} 
A abordagem histórico-analítica que se buscou desenvolver ao longo da monografia fornece subsídios mais consistentes para caracterizar o Sul da Ásia qualitativamente e formular cenários de cooperação ou conflito.

O Sul da Ásia, em termos de processos de securitização, é fundamentado em dois eixos de hostilidade (Índia-Paquistão e Índia-China), que constituem pilares de sustentação de uma agenda de segurança regional pautada na securitização tradicional e na lógica estatal. Os EUA e, em menor medida, a Rússia são potências externas ao complexo que exercem influência sobre a constituição de percepções de ameaça no âmbito regional, são capazes de mediar ou fazer deteriorar tensões nos eixos estruturantes, mas são incapazes de transformá-los definitivamente, uma vez que a polarização no Sul da Ásia é consequência de desenvolvimento histórico.

Entremeando os três pilares, há Estados periféricos em termos de capacidade militar, que correspondem a objetos e não a atores no jogo de poder dos três grandes e, portanto, não modificam percepções ou processos de securitização nos eixos estruturantes. Esses Estados periféricos pleiteiam securitizar temas não-convencionais, mas não têm sucesso em instituir suas demandas na agenda regional. Nos flancos lindeiros do complexo, Afeganistão e Mianmar incorporam temas originais à agenda regional. $O$ terrorismo no Afeganistão e a institucionalização comercial da ASEAN exercem influência no CRS, podendo constituir vetores de transformação qualitativa a depender do grau de abertura conjuntural da agenda tradicional do complexo.

A partir daí, como formular cenários de cooperação e de conflito para o Sul da Ásia? Como a caracterização que se buscou fazer para o complexo acabou sendo holista, mas complexa, será necessário trabalhar com hipóteses simples e consagradas pela literatura de RI, definidas na última seção da primeira parte. Cada uma das hipóteses apresentadas será brevemente discutida, com o objetivo de que o todo constitua análise de cenário significativa. Como muitos elementos factuais já foram apresentados anteriormente, acredita-se que a seguinte análise será quase automática após entendidas outras partes da monografia.

Para a hipótese chamada de realista clássica, haveria conflito caso atores adotassem políticas revisionistas ou imperialistas com relação ao ordenamento do complexo. De fato, tentativas de aquisição territorial por parte de Estados ou de autodeterminação por parte de grupos infra ou transnacionais teriam consequências severas para o desencadeamento de hostilidades no Sul da Ásia. A Caxemira é região crítica para essa hipótese, uma vez que as 
fronteiras estatais não são asseguradas juridicamente ou vistas como legítimas pelos Estados da região. A dissuasão nuclear e a criminalização da expansão territorial pela comunidade internacional são fatores que reduzem a viabilidade da hipótese realista. $\mathrm{Na}$ fronteira entre Paquistão e Afeganistão e também quanto aos demais grupos infraestatais que foram observados nos países periféricos, a hipótese de autodeterminação não se apresenta factível porque se espera que eventuais movimentos de revisão da carta territorial sejam mediados pelos poderes regionais e por atores externos, com marcado conservadorismo.

Quanto às hipóteses neorrealistas, pode-se analisá-las em conjunto, uma vez que a condição de anarquia é imediatamente satisfeita por consideração da estrutura sistêmica e por razão do tipo de interação que se observa no Sul da Ásia. À luz da condição de nuclearização da região, no entanto, ambas as hipóteses neorrealistas parecem pouco prováveis, embora possíveis. Uma vez que a retaliação nuclear já é possibilidade efetiva na região, não é esperado que os atores se sintam ainda mais ameaçados por desenvolvimentos da corrida armamentista que opera na região. É certo que inovações tecnológicas ou ganhos estratégicos ainda geram ameaças recorrentes no Sul da Ásia, mas a hipótese neorrealista defensiva é enfraquecida pela imensa capacidade de retaliação de que dispõem os atores no estágio atual.

Da mesma forma, a condição nuclear também inibe a disposição dos atores em engajarem-se em conflito para assegurar ganhos políticos, a menos que tais ganhos não sejam suficientemente significativos para que outro ator retalie com armas nucleares. O cenário mais provável de escalada de conflito sob essa hipótese é o engajamento em combate direto entre Índia e Paquistão, com eventual uso de armas nucleares táticas por parte deste, seguido de retaliação desproporcional com armas nucleares estratégicas por parte da Índia. A hipótese neorrealista ofensiva dependeria de um conflito iniciado por variável exógena a seu preceito, não sendo suficiente, portanto, para justificar o primeiro ato de combate descrito.

Segundo a hipótese do choque de civilizações, a interação entre civilizações leva ao conflito porque não há base de harmonia entre identidades civilizacionais. De fato, aspectos culturais são importantes ferramentas de diferenciação e de mobilização das populações assentadas no Sul da Ásia com importantes consequências para a interação política dos atores analisados. A imposição histórico-geográfica de interação aos islâmicos e hindus no espaço indiano está na origem das disputas que culminaram na criação de dois Estados diferentes em 1947. Todavia, já no momento de alocação territorial pós-independências, a lógica estatal superou a lógica civilizacional, instrumentalizando áreas de homogeneidade cultural para 
constituir base de soberania política, mas ignorando áreas de diferença em nome da continuidade territorial dos novos Estados. A partir da segunda metade do século XX, durante o tempo de vida do complexo de segurança, a lógica estatal consagrou-se como motivação mais importante na constituição de interesses e ações políticas no Sul da Ásia.

Como atores não-estatais ainda são muito influenciados pelo tipo de extremismo identitário presente no preceito desta hipótese, espera-se que surjam futuros conflitos envolvendo atores não-estatais no Sul da Ásia, muito embora não haja qualquer tendência clara de que esses conflitos escalariam para o nível de rivalidade estatal. A lógica estatal pode esboroar e ceder espaço para a lógica civilizacional se prosseguir o passo de enfraquecimento do Estado paquistanês. Nesse cenário, atores infra e transnacionais substituiriam as instituições nacionais ou delas apropriar-se-iam, constituindo novo signo de identificação e vinculação de lealdades.

As hipóteses construtivistas apresentam as duas possibilidades de cenário, variando o tipo de cultura perpetuada no complexo. A cultura de rivalidade existente entre Índia e Paquistão e entre Índia e China tem efeitos visíveis sobre a perpetuação de desconfianças no Sul da Ásia. A partição da Caxemira, realizada por recurso ao uso da força em 1947 e em 1962, é ainda o símbolo-âncora da cultura de rivalidade no Sul da Ásia. As hipóteses construtivistas são atípicas, porque são subjacentes a outras hipóteses destacadas. Discursos de diferenças civilizacionais e de inimizade histórica, bem como as políticas de dissuasão nuclear e o choque entre projeções de influência sobre Tibete, Nepal e Butão constituem fatores de alimentação de cultura outrora estabelecida. Como a cultura tende a se perpetuar em cadeia de constituição de interesses e comportamentos, o cenário mais imediato para as hipóteses construtivistas é o da perpetuação do conflito.

Todavia, a segunda hipótese construtivista abre possibilidades de cooperação na medida em que iniciativas de construção de cultura de paz - como a iniciada com a paz de Lohore, na sequência da crise de 1998 - tendem a perpetuar-se e a ganhar densidade conforme passa o tempo. Não é possível dizer que a segunda hipótese construtivista seja factível no atual estágio do CRS, mas certamente é uma possibilidade para médio e longo prazo.

Demais hipóteses de cenário de cooperação também apresentam moderado grau de viabilidade. Segundo a hipótese idealista clássica, a cooperação adviria da percepção compartilhada de ganhos com a harmonia, o que está em consonância com a proposta da síntese institucionalista que enfatiza o papel da preocupação com ganhos absolutos. Ambas 
essas concepções são refletidas no adensamento da agenda econômica entre China e Índia a partir do final da crise de Kargil. Não é possível assegurar que os benefícios mútuos de Índia e China na interação comercial resultem em pacificação da agenda de segurança definitivamente, mesmo porque a clivagem burocrática dentro da própria China prejudica esse cenário, mas ainda assim é preciso reconhecer que o incremento de intercâmbio comercial certamente é variável causal de vetor oposto a esse eixo de conflito.

Segundo a hipótese das ordens institucionais, a construção de confiança e a confluência de expectativas sobre padrões de comportamento aceitáveis têm o efeito de incrementar a cooperação em um sistema. Nesse sentido, a institucionalização da prática de relatar futuros testes nucleares ou balísticos por parte de Índia e Paquistão, ou ainda o respeito por parte de Índia e China aos Panchsheel, levariam à perpetuação de expectativas sobre o comportamento do rival, que no futuro se transformaria em confiança mútua. Também essa hipótese de cooperação parece bastante viável no longo prazo, embora não haja segurança de sua verificação no atual estágio das interações do Sul da Ásia.

Uma última hipótese de cooperação citada, a da paz democrática, parecia ser relevante quando o processo de construção do gasoduto da paz foi interreompido devido ao extremismo do governo autoritário de Musharraf e ao imobilismo da democracia parlamentar complexa da Índia. Entre 2008 e 2009, tanto o governo autoritário foi deposto do Paquistão, quanto eleições para o Legislativo indiano garantiram maior grau de governabilidade para o país. Essa nova conjuntura não foi suficiente para evitar as hostilidades na relação entre Índia e Paquistão. Ao que parece, as rivalidades no Sul da Ásia são mais dependentes de fatores culturais e materiais do que de fatores ideológicos ou de interação entre regimes políticos.

Finalmente, analisando a grande constelação de hipóteses apresentadas aqui, o que se pode assegurar é que existem forças atuando nos sentidos opostos de cooperação e conflito no complexo de segurança do Sul da Ásia. Tentativas de traçar cenários com base em apenas uma das diversas hipóteses consideradas serão necessariamente simplistas, já que os efeitos de um vetor de força podem facilmente ser solapados pelo conjunto dos demais. Aqueles vetores que parecem mais estruturais e de difícil modelagem para líderes políticos e sociais são as formas de perpetuação de culturas de hostilidade nas interações regionais e é por isso que a tendência de fundo no Sul da Ásia terá sempre meios de deteriorar-se em conflito. Mas, mesmo nesse caso, a hipótese construtivista também considera a possibilidade de cooperação que, embora magra e 
O Complexo Regional de Segurança do Sul da Ásia 61

frágil, também acompanhou a história do CRS evitando que este se colapsasse nas diversas oportunidades de conflito. 


\section{BIBLIOGRAFIA}

ABDUL, Muhammad M. "East Asian Security: A Bangladesh Perspective". In SISODIA, N. S. \& NAIDU, G. V. C. Changing Security Dynamic in Eastern Asia: Focus on Japan. Amritsar: Bibliophile South Asia, 2005, pp. 504-528.

ADLER, Emmanuel \& BARNETT, Michael. Security Communities. Cambridge: Cambridge University Press, 1998. ADLER, Emmanuel. Imagined Security Communities: Cognitive Relations in International Relations. Millennium 26, 1997. ALI, Saleem H. "Water Politics in South Ásia: Technocratic Cooperation and Lasting Security in the Hindus Basin and Beyond". Journal of international Affairs, 61, 2. spring 2008

BAJPAI, Kanti. "Indian Strategic Culture". In CHMBERS, Michael R. (ed). South Asia in 2020: Future Strategic Balances and Alliances. Carlisle Barracks: Strategic Studies Institute, Army War College, 2002, pp. 245-303

BALDWIN, David A. Neorealism and Neoliberalism. New York: Columbia University Press, 1993.

BANDEIRA, Heloíza F. “Mianmar e sua Contagem Regressiva para uma Suposta Transição de Regime”. Boletim Meridiano 47, (95) junho, 2008

BANDEIRA, Luiz Alberto. O Brasil e a América do Sul. in: Altemani, Henrique \& Lessa, Antônio (ed.). Relações Internacionais do Brasil: temas e agendas. Brazil, SP: Saraiva, 2006 pp. 267-298

BRANDT, Willy. North-South: A Programme to Survival. London: Pan Books, 1980.

BRAUDEL, Ferdinand. The Perspective of the World. Civilization and Capitalism vol.3. NY: Harper \& Row, 1984

BRECHER, Mivhael. International Relations and Asian Studies: the subordinate state system and Southern Asia. World Politics 1963, 15, pp.231-235.

BRYANT, Edwin The Quest for the Origins of Vedic Culture: The Indo-Aryan Migration Debate. Oxford: Oxford University Press, 2004.

BUSSMANN, Margrit \& ONEAL, Jhon. Can a Hegemon Distribute Private Benefits to Its Allies? A test of power-transition theory. Journal of Conflict Resolution, Vol. 51, No. 1, 88-111 (2007)

BUZAN, B.; WAEVER, O. \& WILDE. Security: a new framework for analysis. Cambridge: Cambridge University Press, 1998.

BUZAN, Barry \& WAEVER, Ole. Regions and Powers: The Structure of International Security. Cambridge: Cambridge University Press. 2003.

BUZAN, Barry. "The level of analysis problem in international relations reconsidered". In: Booth, Ken; Smith, Steve. International Relations Theory Today. Cambridge: Polity Press, 1995.

BUZAN, Barry. People, states, and fear: The national security problem in international relations. Brighton: Wheatsheaf, 1983.

CARDOSO, K., PEREIRA, P., NAKAMURA, L. \& OLIVEIRA, L. The Indian Caste System and the Issue of Untouchability. In MACHADO, A. IDE, D. \& ZAGO, E. Toward Global Identity Through Cultural Diversity. Brasília: UNESCO, 2009.

CHA, Victor D. Globalization and the Study of International Security. Journal of Peace Research, 2000 n. 37 v.3 pp. 391-403.

CHANDAVARKAR, Rajnarayan. Imperial Power and Popular Politics: Class, Resistance and the State in India, 1850-1950. Cambridge: Cambridge University Press, 1988

CLARK, I. Globalization and Fragmentation: international relations in the twentieth century. New York: Oxford University Press, 2004

DEEGALE, Mahinda. "Norms of War in Theravada Buddhism”. In POPOVISKI, V., M. REICHBERG, G. \& TURNER, N. World Religions and Norms of War. New York: United Nations University Press, 2009

DEUTSCH, K. \& Foltz, W. (eds.). Nation Building. Atherton Press, 1963

DEUTSCH, Karl et al. Political Community in the North Atlantic Area. Princeton: Princeton University Press, 1957 
DEUTSCH, Karl. "Security Communities". In: Rosenau, James (ed.), International Politics and Foreign Policy. New York: Free Press, 1961

DICICCO, Jonathan, \& LEVY, Jack. The Power Transition Research Program: A Lakatosian Analysis in Colin Elman and Mirium Fendius Elman, eds., Progress in International Relations Theory: Appraising the Field. MIT Press, 2003.

DITTMER, Lowell, (ed.) South Asia's Nuclear Security Dilemma: India, Pakistan, and China. Armonk, New York: M.E. Sharpe, 2005.

DOPCKE, Wolfgang \& MASCHIETO, Roberta. The Development of Regional Security Architecture in Southern Africa (SADC). in: VAZ, Alcides. (2006)

DORN, Walter. Regional Peacekeeping Is not the Way. Peacekeeping and International Relations, v. 27 n.3-4, 1998.

DUFFIELD, Mark. Global Governance and the New Wars: The Merging of Development and Security. London: Zed Books, 2001

EWANS, Martin. The Great Game: On the Practicability of an Invasion of British India. NY: Routledge, 2004

FAWCETT, Luise \& HURREL, Andrew (Ed.). Regionalism in World Politics. Oxford: Oxford University Press, 1995.

FAWCETT, Luise. Exploring Regional Domains: A Comparative History of Regionalism. International Affairs 80, 3 , 2004.

FERGUSON, Y. H. \& MANSBACH, R. H. The Past as Prelude to the Future? Identities and Loyalties in Global Politics. Colombia: University of South Carolina Press, 1996

FLAMES, Daniel. Conceptualising Regional Power in International Relations: lessons from the South African Case. GIGA Research Programme: Power, Violence and Security. N 53. June, 2007

FOUCAULT, Michel. Society Must Be Defended. London: Penguin Books, 2004

GANGULY, Sumit. "Pakistan's Never-Ending Story: Why the October's coup was no surprise”. Foreign Affairs, March/Aprl. 2000

GAT Azar. War in Human Civilization. Oxford and New York: Oxford University Press, 2006.

GAUSE, III, F. Gregory. “The International Politics of the Gulf”. In: Fawcett, Louise (ed.). International Relations of the Middle East. Oxford: Oxford University Press, 2008

GIDDENS, Anthony. Sociologia. Porto Alegre: Artmed, 2005.

GILPIN, Robert. Global Political Economy. Princeton: Princeton University Press, 2001.

GILPIN, Robert. War \& Change in Word Politics. Cambridge: Cambridge University Press, 1981.

GRAMSCI, Antonio. Selections from the Prison Notebooks. International Publishers, 1971

GREENSTOCK, Jeremy. Refashioning the Dialogue: Regional Perspectives on the Brabimi Report in UN Peace Operations. New York: International Peace Academy, 2001.

GUEHENNO, Jean-Marie. The Impact of Flobalization in Strategy. Survival, 1998 v. 40 n.4 pp.5-10.

HAAS, Richard. "Naval Arms Limitation in the Indian Ocean”. Survival, 20 March-April, 1978

HANSEN, Birthe. Unipolarity and the Middle East. Richmond, Surrey: Curzon Press, 2000

HARLE, J.C. The art and architecture of the Indian Subcontinent. New Haven, Conn: Yale University Press, 1994

HASENCLEVER, Andreas et al. Integrating Theories of International Regimes. In Review of International Studies 26, 2000.

HETTNE, Björn \& SÖDERBAUN, Fredrik. (1998). "Theorising the rise of regionness," in: Breslin, Shaun et al., New Regionalisms in the Global Political Economy. London/ New York: Routledge, 2002 pp. 33-47;

HOBSBAWN, Eric. Era dos Extremos. O breve século XX: 1919-1991. São Paulo: Cia das Letras, 2009

HUNTINGTON, Samuel P.. “The Clash of Civilizations”. Foreign Affairs. Summer, 1993

HURRELL, Andrew. "Explaining the resurgence of regionalism in world politics". Review of International Studies, 1995, 21. 
JACKSON, R. H. Governing Globalization - Power Authority and Global Governance. Cambridge: Policy Press, 2002.

JALAL, Ayesha. The Sole Spokesman: Jinnah, the Muslim League and the Demand for Pakistan, Cambridge, UK: Cambridge University Press, 1993

JERVIS, Robert. Security Regimes. In KRASNER, Stephen (Ed.). International Regimes. Ithaca: Cornell University Press, 1995.

KAGAN, Robert. Of Paradise and Power: America and Europe in the New World Order. New York: Random House, 2004.

KANT, Immanuel. À Paz Perpétua. Porto Alegre: L\&PM, 1989.

KATZENSTEIN, Peter J. (ed). The Culture of National Security Norms and Identity in World Politics. New York: Columbia University Press, 1996

KATZENSTEIN, Peter J. "Why is there no NATO in Asia: collective identity, regionalism, and the origins of multilateralism”. International Organization, Vol. 56, No. 3 (Summer, 2002), pp. 575-607

KEOHANE, Robert \& Nye, Joseph. Power and Interdependence. World Politics in Transition. Boston, Little-Brown, 1977

KEOHANE, Robert O. International Institutions and State Power. Boulder: Westview, 1989.

KEOHANE, Robert. After hegemony: Cooperation and discord in the world political economy. Princeton: Princeton University Press, 1984

KEOHANE, Robert. Neorealism and its critics. New York: Columbia University Press, 1986.

KHALIZAD. Security in Southern Asia: The security of southeast asia. Aldershot: Gower, 1984.

KNORR, Klaus \& ROSENAU, James (Eds). Contending approaches to international politics. Princeton, New Jersey: Princeton University Press, 1969.

KNUDSEN, Olav. Post-Copenhagen security studies: desecuritizing securitization. Security Dialogue, Vol. 32 (3), 2001.

KRASNER, Stephen. Structural Conflict: the third world against global liberalism. Berkeley: University of California Press. 1985

LAKE, David "Reconceptualizing Regions: A Systems Approach," in David A. Lake and Patrick M. Morgan, eds., Regional Orders: Building Security in a New World. University Park PE: The Pennsylvania State University Press, 1997.

LAKE, David \& MORGAN, Patrick. The New Regionalism in Security Affairs. In LAKE, David \& MORGAN, Patrick. Regional Orders Building Security en a New World. University Park PE: The Pennsylvania State University Press, 1997.

LECHINI, Gladys. Middle Powers: IBS A and the New South-South Cooperation. NACLA Report on the Americas. New York: Sep/Oct 2007.

LEMKE, Douglas. Regions of W ar and Peace. Cambridge: Cambridge University Press, 2002.

LI, Li. "India's Security Concept and its China Policy in the Post Cold War Era". Chinese Journal of International Politics, Vol. 2, 2008, 229-261

LIMA, Maria Regina \& HIRST, Monica. Brazil as an Intermediate State and Regional Power: action, choices and responsibilities. International Affairs. 82, I, 2006, 21-40

MACHADO, Artur A. "Testes Balísticos no Sul da Ásia: A relação Índia-Paquistão". Boletim Meridiano 47 (95) Junho p.34, 2008.

MACHADO, Artur. A. \& TORRES, H. (Foreseing publication) The Regional Cutting Edge for the Globalization: Why is that important to study regions in a globalized world?

MACKINDER, H. J. "The Geographical Pivot of History," The Geographical Journal 23, April, 1904. pp 421-444.

MAJUNDAR, R. C. (Ed). The History and Culture of the Indian People. London: George Allen \& Unwin Ltd, 1951.

MALIK, Mohan. "China and the Nuclear Non-Proliferation Regime”. Countemporary South-East Ásia,22. 2000

MALIK, Mohan. “The China factor in the India-Pakistan conflict”. Parameters, 33,1. Spring 2003 
MALIK, Mohan. "The Stability of Nuclear Deterrence in South Asia: The Clash Between State and Anti-state Actors". Asian Affairs, Heldref Publications, 1996

MANSFIEL, Edward D. \& MILNER, Helen V. "The New Wave of Regionalism" in Diehl, Paul F. The Politics of Global Governance: International Organizations in an Interdependent World. Boulder: Lynne Rienner Publishers, 2005.

MEARSHEIMER, John. Conventional Deterrence. Ithaca: Cornell University Press, 1998

MEARSHEIMER, John. The Future of the American Pacifier. Foreign Affairs, 2002, Sept/Oct.

MERSHEIMER, John. The Tragedy of Great Powers Politics. New York: Norton Paperback, 2003

MILNER, Helen V., "International Trade" in Carlsnaes, Walter; Thomas Risse, Beth A. Simmons (2002). Handbook of International Relations. London: SAGE Publications., 2002.

MILNER, Helen. "International Theory of Cooperation Among Nations: Strengths and Weaknesses. World Politics, 1992, 44.

MORGAN, Gerald, "Myth and Reality in the Great Game," Asian Affairs, vol. 60, February 1973

MORGENTHAU, Hans. A Política entre as Nações. São Paulo: Editora Universidade de Brasília, 2003.

NAVARRETE, Jorge. El G8 y los Otros Cinco: el rol de Mexico. Friedrich Ebert Stifung, 2008

NEUMAN, Stephanie (Ed.). International Relations and the Third World. New York: St. Martin's Press, 1998.

NYE, J. (ed.). International Regionalism. Boston: Little, Brown, 1968

NYE, J. Peace in Parts: Integration and Conflict in Regional Organization. Boston: Little, Brown, 1971.

NYE, J. Soft Power: The means to success in world politics. New York: Public Affairs, 2004.

NYE, J. "A Glass Half Full”. Japan-US Security Relations: a testing time for the alliance. CSIS, Pacific Forum Conference Report, 2009

ONUF, Nicholas. Levels. European Journal of International Relations, 1995, v.1, no. 1.

ORGANSKI, AFK. World Politics. New York: Chatham House. 1958

PANT, N.K. “Is China Wanting to Have an Indo-Pak War?”. Free Press Journal, Washington 2002

PATRIOTA, Antonio A. O Conselho de Segurança após a Guerra do Golfo. A articulação de um novo paradigma de segurança coletiva. Brazil, Brasília: Fundação Alexandre Gusmão, 1998.

PEDERSEN, Thomas. Cooperative Hegemony: power, ideas and institutions in regional integration. Review of International Studies. 2002. no 28. pp. 677-696

PINTO, P.A.P. “China e Índia - Chíndia (II): vasta estrutura econômica em construção”. Boletim Meridiano 47, (94) Maio 2008.

PRZEWORSKI, Adam \& TEUNE, Henry. The logic of comparative social inquiry. NY: Wiley-Interscience, 1970

PUGH, Michael \& PAL, Waheguru (Ed.). The United Nations and Regional Security: Europe and Beyond. Boulder Co: Lynne Rienner, 2003.

RAIS, Rasul Bux. The Indian Ocean and the Superpowers. New Jersey: Barnes \& Noble Books, 1986

RANDOL, Shaun. "How to Approach the Elephant: Chinese perceptions of India in the twenty-first century". Asian Affairs. Heldref Publications, 2008, pp. 211-226

RAPKIN, David. "Power Transition, challenge and the (re)emergence of China”. International Interactions. 2003. 29, pp.315-342

RAWLS, John. The Law of Peoples. Massachusetts: Harvard University Press, 2002

RICHARDS, John F. The Mughal Empire.Cambridge University Press, 1996

RITTBERGER, Volker (ed.). Regime Theory and International Relations. Oxford: Oxford University Press, 1993

RIZVI, Hasan-Askari. Military, State and Society in Pakistan. New York: St. Martin's Press, 2000

RUSSETT, B. International Regions and the International System: A Study in Political Ecology. Chicago: Rand McNally, 1967 
SARAIVA, J.F.S. (Org.) História das Relações Internacionais Contemporâneas: da sociedade internacional do século XIX à era da globalização. São Paulo: Editora Saraiva, 2007

SCHOTT, Jeffrey J. "Trading blocs and the world trading system". World Economy 14 (1): 1-17. 1991

SCHULZ, Michael, SODERBAUM, Fredrik \& OJENDAL, Joakim. Regionalization in a Globalizing World: $A$ Comparative Perspective on Forms, Actors and Process. London: Zed Books, 2001.

SEN, Amartya. The Argumentative Indian. Writings on Indian Culture, History and Identity. London: Penguin Books, 2005

SENEVIRATNE, H.L. The Work of Kings: The New Buddhism in Sri Lanka Chicago: University of Chicago Press, 1999

SHAA, S.A.A. "Russo-India Military-technical Cooperation". Journal of the Institute of Strategic Studies, Islamabad. No.4, 2001

SHALOM, Stephen R. "The Men Behind Yahya in the Indo-Pak War of 1971"

SHAMASASTRY, R. Kautilya's Arthashastra. Mysore: Wesleyan Mission Press, 1923.

SHAPIRO, Michael C. (2003), "Hindi". In CARDONA, GEORGR \& DHANESH, The Indo-Aryan Languages, Routledge, 2003

SHEE, Poon Kim. "The Political Economy of China-Myanmar Relations: Strategic and Economic Dimensions". Ritsumeikan Annual Review of International Studies, 2002, pp. 33-53

SHUJA, Sharif. "Pakistan: Islam, Radicalism and the Army". International Journal on World Peace; Jun 2007; $24,2$.

SIEGEL, Jennifer. Endgame: Britain, Russia and the Final Struggle for Central Asia. London: I.B. Tauris, 2002

SINGER, J. David. The Level-of-Analysis Problem in International Relations. World Politics, 1961, 14, No. 1.

SLUGLETT, Peter (2008). "The Cold War in the Middle East". In: Fawcett, Louise (ed.). International Relations of the Middle East. Oxford: Oxford University Press.

SRINIVAS, V.N. "Trends in Defence Expenditure: India, China and Pakistan". Air Power Journal, Vol. 3, No. 1, Spring 2006

STONE, Sweet, Alec, \& WAYNE, Sandholtz. Integration, supranational governance, and the institutionalization of the European polity. In Wayne Sandholtz, Alec Stone Sweet (Eds.), European integration and supranational governance. Oxford: Oxford University Press, 1998.

STRANGE, S. "Cave! Hic Dragones: A critique of Regime Analysis". in: Krasner, Stephen (ed.). International Regimes. Ithaca, NY: Cornell University Press. 1983

Surjit Mansingh, India’s Search for Power: Indira Gandhi’s Foreign Policy 1966-1982 (New Delhi: Sage Publications, 1984), pp. 13-1

TAKAHASHI, Hideyuki. "Maldivian National Security -And the Threats of Mercenaries". The Round Table, No. 351, July 1999, pp. 433-444

TAMBIAH'S, Stanley Jeyeraja. Buddhism Betrayed? Religion, Politics, and Violence in Sri Lanka. Chicago: University of Chicago Press, 1992

THOMAS, Raju G. C. The Defense of India - A Budgetary Perspective of Strategy and Politics. New Delhi: MacMillan, 1978

THOMPSON, William. The Regional Subsystem: A Conceptual Explication and a Propositional Inventory. International Studies Quarterly 17, 1973.

TICKNER, J. Ann, Re-visioning Security. In BOOTH, Ken \& SMITH, Steve. International Relation Theory Today. Oxford Polity Press, 1995.

TINKER, Hugh. Índia and Pakistan: a political analyzis. London: Pall Mall Pres, 1967

TÖNNIES, Ferdinand, Community and Civil Society. Cambridge: Cambridge University Press, 2001

ULLMAN, Richard. Redefining Security. International Security v.8 n.1, 1983.

VASUDEVAN, Geeta. Royal Temple of Rajaraja: An Instrument of Imperial Cola Power. New Delhi: Abhinav Publications, 2003. 
VÄYRYNEN, Raimo. Regionalism: old and new. International Studies Review, 5, 2003.

VAZ, Alcides (Ed.). Intermediate States, Regional Leadership and Security: India, Brazil and South Africa. Brasilia: Editora Universidade de Brasília, 2006.

VENKATACHAR, C.S. "Sea Power in the Indian Ocean”. New Delhi: Eastern Economic Pamphlets, no.352-353. jul-oct. 1953.

WAINWRIGHT, Martin. Inheritance of Empire: Britain, India, and the Balance of Power in Asia, 1938-55, Praeger Publishers, 1993

WALT, Stephen. The Origins of Alliances. Ithaca: Cornell University Press, 1987

WALTZ, Keneth. Theory of International Politics. New York: McGraw-Hill, Inc, 1979.

WATSON, Adam. A Evolução da Sociedade Internaciona: uma análise histórica comparatival. Brasília: Editora da Universidade de Brasília, 2004

WEISS, Thomas (Ed.). Beyond UN Subcontracting: Task-Sharing with Regional Security Arrangements and Service-providing NGOs. London: Macmillan, 1998.

WENDT, Alexander. Social Theory of International Politics. Cambridge, Cambridge University Press, 2007.

WIRSING, Robert G. "The Hydro Politics in South Asia: The domestic roots for inter-state river rivalry", Asian Affairs. Heldref Publications, 2007

YURDUSAY, A. Nuri. “Level of Analysis' and 'Unit of Analysis': A Case for Distinction”. Millenium: Journal of International Studies, 1993 22, no. 1.

ZAGO, Evandro F. "Noroeste Paquistanês em Crise: a Guerra contra o terror e o avanço do Talibã”. Boletim Mundorama, Junho, 2009

ZARTMAN, William. Africa as a Subordinate State System in International Relations. International Organization 1967. 21, pp.545-564. 